\title{
Intercellular signals regulating pancreas development and function
}

\author{
Seung K. Kim ${ }^{1,3}$ and Matthias Hebrok ${ }^{2}$ \\ ${ }^{1}$ Departments of Developmental Biology and Medicine, Division of Oncology, Stanford University, Stanford, California, \\ 94305-5329, USA; ${ }^{2}$ Diabetes Research Center, Department of Medicine, University of California, San Francisco, California \\ 94143-0573, USA
}

Classic studies of dissected and recombined embryonic pancreas tissues published four decades ago suggested that epithelial-mesenchymal cell interactions regulate growth, epithelial branching, and cell differentiation in the embryonic pancreas (Golosow and Grobstein 1962; Wessells and Cohen 1967). Modern studies have revealed additional cell interactions, involving pancreatic epithelium and midline mesoderm-derived tissues, essential for normal pancreatic development (Kim et al. 1997a). Recently, many of the signaling pathways likely to govern cell interactions in the developing pancreas have been identified, allowing detailed studies of the genetic, molecular, and cellular basis of intercellular signaling that establishes proper pancreas development and function. These include the transforming growth factor- $\beta$ (TGF- $\beta)$, Notch, Hedgehog, fibroblast growth factor (FGF), and epidermal growth factor (EGF) pathways, and investigation of pancreas developmental biology demands familiarity with these signaling pathways. Descriptions of these pathways may be found in several recent reviews (Artavanis-Tsakonas et al. 1999; Hackel et al. 1999; Massagué and Chen 2000; Bailey et al. 2000; McMahon 2000; Zaret 2000).

Our understanding of intercellular signals that regulate pancreatic development and function has advanced in the last several years. Knowledge about the role of transcription factors in pancreatic development, function, and disease has also rapidly advanced and has been recently reviewed (Sander and German 1997; Edlund 1998; Dohrmann et al. 2000). Here we emphasize findings that may elucidate mechanisms underlying human pancreatic exocrine and endocrine diseases, including congenital malformations and diabetes mellitus, and examine areas that need to be addressed to advance our understanding of pancreas development and function. We also discuss known or probable relationships between cell-extrinsic pancreatic signaling and transcriptional regulators of pancreatic gene expression. Additional literature may be found in several previous re-

\footnotetext{
${ }^{3}$ Corresponding author.

E-MAIL seungkim@cmgm.stanford.edu; FAX (650) 725-7739.

Article and publication are at www.genesdev.org/cgi/doi/10.1101/ gad.859401.
}

views (Slack 1995; Kim et al. 1997b; Gannon and Wright 1999; Yamaoka and Itakura 1999). References have been abridged here: for complete reference listings, annotated legends, and table, please see http://seungkimlab.stanford.edu.

\section{Outline of pancreas development \\ Morphogenesis and cell differentiation}

The mature pancreas has morphologically and functionally distinct endocrine and exocrine components. The exocrine portion, including acinar and duct cells, comprises $95 \%-99 \%$ of the pancreas and produces digestive enzymes that promote nutrient digestion and absorption in the gut. Mature endocrine cells are located in islets of Langerhans, discrete endoderm-derived cell aggregates scattered throughout the exocrine pancreas. Islets contain four principal endocrine cell types, defined by the hormones they secrete. These include insulin-producing $\beta$-cells, glucagon-producing $\alpha$-cells, somatostatin-producing $\delta$-cells, and pancreatic polypeptide-producing PPcells.

Early pancreatic development has been particularly well studied in mice and chickens, and important similarities and differences in pancreatic morphogenesis in these species have been previously described (DieterlenLièvre 1970; Dieterlen-Lièvre and Beaupain 1974; Kim et al. 1997b). Here we briefly outline pancreatic development in mice. During embryogenesis, the pancreas develops from distinct dorsal and ventral anlagen. Before specification toward a dorsal pancreatic fate, midline endoderm in posterior foregut is a single layer of epithelial cells that contacts notochord, an axial mesoderm-derived structure (Fig. 1). Laterally, endoderm fated to form ventral pancreas is adjacent to both splanchnic mesoderm and aortic endothelial cells but is not in direct contact with notochord. The notochord and dorsal prepancreatic endoderms remain in contact until about the 13-somite stage in mice, $8.5 \mathrm{~d}$ postcoitum (dpc), when midline fusion of the paired dorsal aortas occurs. The first indication of morphogenesis occurs at 22-25 somites in mice $(9.5 \mathrm{dpc})$, when dorsal mesenchyme condenses and underlying endoderm evaginates, forming a 
A
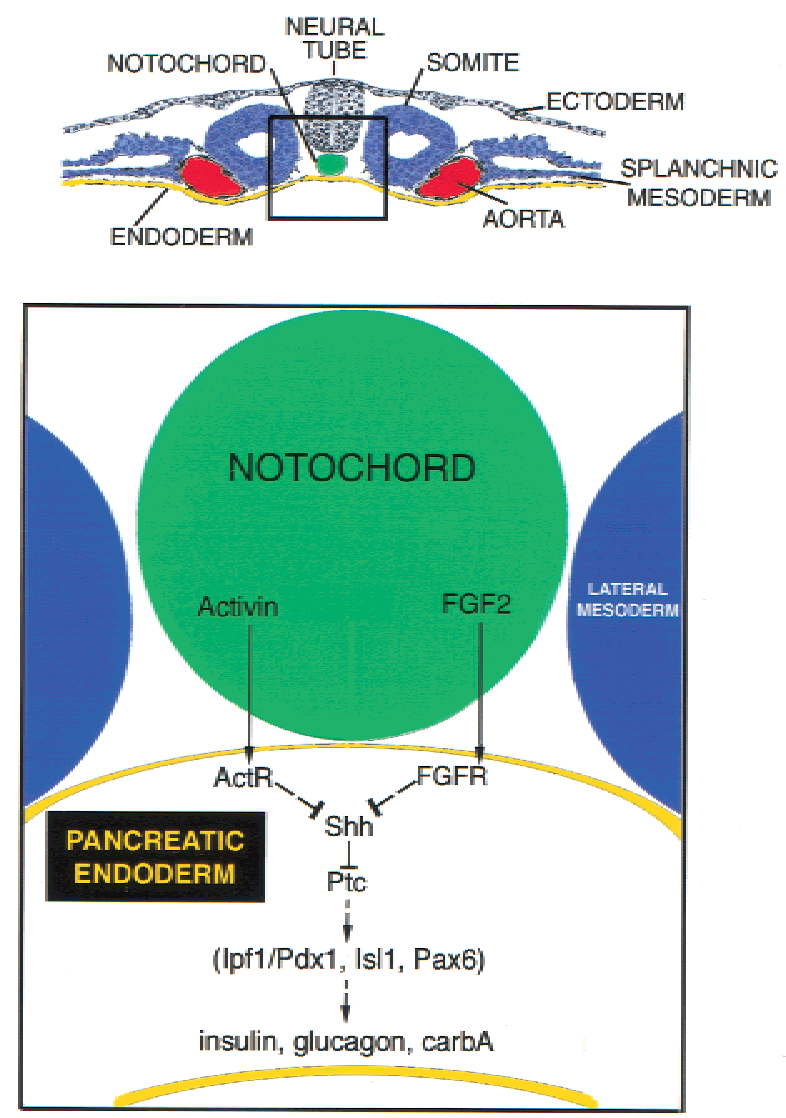

B
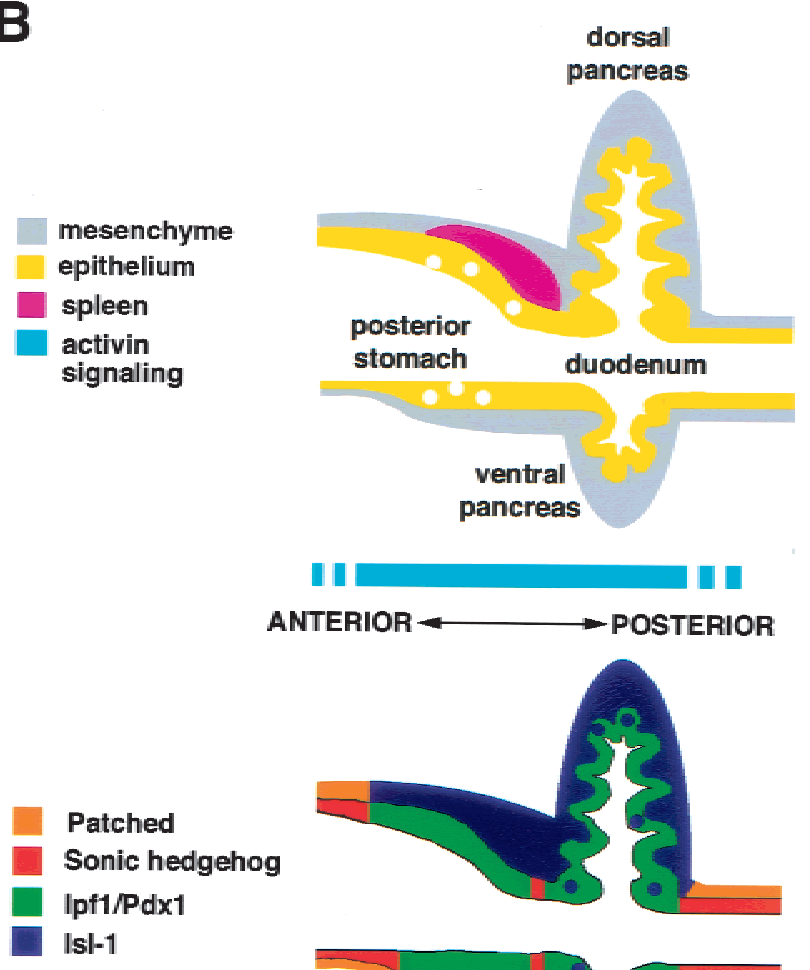

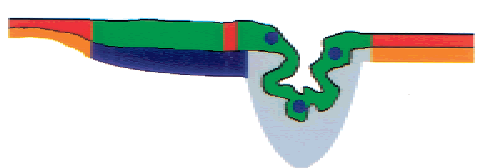

Figure 1. Cell interactions and intercellular signaling in pancreas development. $(A)$ Top: Relationships of prepancreatic endoderm and notochord to adjacent tissues in transverse section. Boxed area shown in greater detail below. Bottom: summary of signaling pathways thought to regulate pancreatic endodermal gene expression. Established interactions between molecules indicated by solid lines with arrows $(\downarrow)$ denoting stimulation and blunt lines $(+)$ denoting inhibition of activity. Indirect interactions indicated by dashed lines, with arrowheads denoting stimulation, and blunt lines indicating repression of target gene expression. ActR $=$ activin receptor. FGFR = fibroblast growth factor receptor. Other abbreviations described in text. $(B)$ Schematic summary of morphology $($ top $)$ and gene expression (bottom) in sagittal view of the midgestational posterior foregut $(\sim 13.5 \mathrm{dpc}$ in mice). At this stage, spleen morphogenesis within the dorsal gastric mesoderm is evident. Expression of type II activin receptors in endoderm summarized by the teal bar. Anterior/posterior axis marked by double-headed arrow.

recognizable dorsal pancreatic bud; the ventral bud appears later at $\sim 30$ somites $(10.25-10.5 \mathrm{dpc})$. Stimulated by mesenchymal signals, pancreatic epithelial cells proliferate and branch. The accumulated evidence is consistent with the possibility that a unique cell gives rise to all pancreatic cell lineages. The existence of such a pancreatic "stem" cell remains debatable, in part for lack of adequate in vivo functional reconstitution assays like those that allowed purification of hematopoietic stem cells at the end of this century (for review, see Weissman 2000). Also, with important exceptions (Herrera et al. 1994; Herrera 2000), nearly all prior studies of pancreatic cell lineage have been based on dynamic patterns of gene expression instead of indelible cell tracers. As the work of others has emphasized (Cepko et al. 1993; Percival and Slack 1999), definitive cell lineage considerations cannot be based merely on studies of transiently expressed genes.

In mice, soon after specification of the pancreatic anlage in posterior foregut endoderm at $\sim 8.5 \mathrm{dpc}$, somato- statin mRNA becomes detectable, marking the beginning of endocrine cell differentiation (Herrera et al. 1991; Gittes and Rutter 1992). Immunohistochemistry demonstrates the appearance of scattered cells expressing insulin or glucagon by $9.5 \mathrm{dpc}$. Development of exocrine cells into acini and ducts is recognizable by $14.5 \mathrm{dpc}$; at this stage, endocrine cells are found embedded as individual cells in ducts or in small cell clusters distinct from ducts. In mice, the stereotyped architecture of islets with central insulin-expressing $\beta$-cells surrounded by non- $\beta$ cells is detected late in gestation (by $18 \mathrm{dpc}$; Fig. 2). In adult birds, rodents, and humans, islet cell composition differs in the dorsal and ventral pancreas (Orci and Unger 1975; Orci 1982; Kim et al. 1997b), and islet and pancreatic perfusion studies have demonstrated that dorsal islets release more insulin than ventral islets in response to glucose stimulation (Trimble et al. 1982; Stefan et al. 1987). There are about one million islets in the human pancreas, several hundred to a few thousand in the rat (Hughes 1956), and one or two Brockmann bodies (islet- 


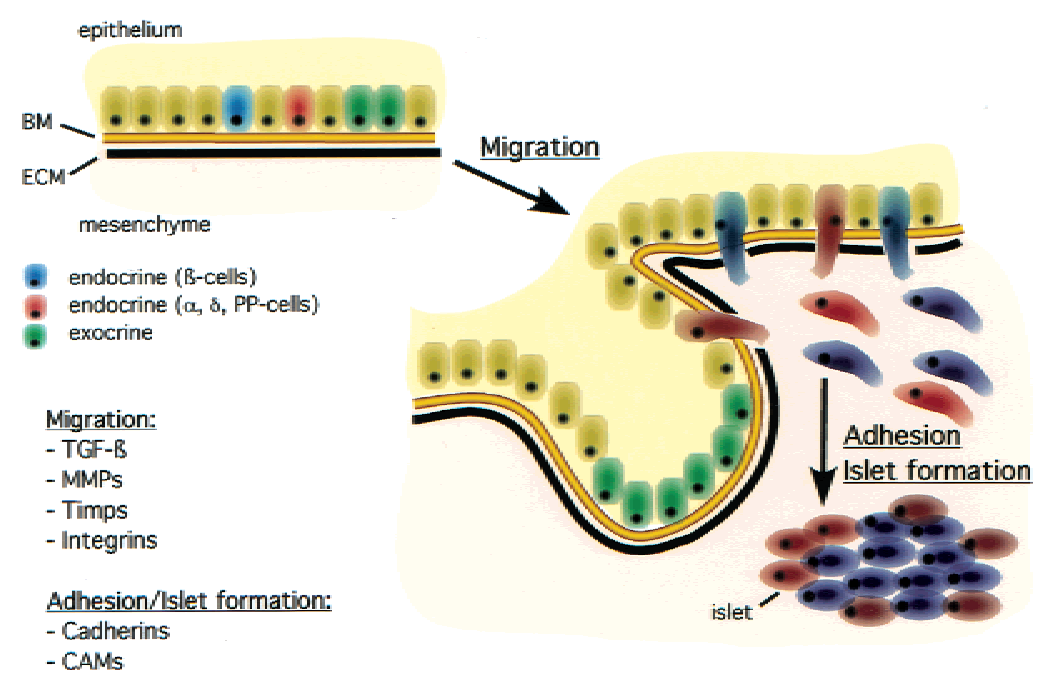

Figure 2. Epithelial branching and islet morphogenesis. Before branching morphogenesis, presumptive endocrine and exocrine precursor cells can be identified in the epithelium of the dorsal and ventral pancreas. Exocrine precursors localize at the distal tips of the epithelial ducts when the epithelium branches into the surrounding mesenchyme. Concurrently, endocrine islet precursors migrate through the basal membrane and extracellular matrix that separates epithelium and mesenchyme. Metalloproteinases (MMP's) and their inhibitors (TIMP's) regulate endocrine cell migration through degradation of basal membrane (BM) and extracellular matrix (ECM) molecules. Integrins, cell surface receptors that bind to ECM molecules, mediate cell adhesion and movement. Generation of mature islets requires cell adhesion molecules, including cadherins and CAMs, that organize the different endocrine cells to achieve characteristic islet architecture. like structures) in zebrafish. There is also a rough linear correlation between islet mass and animal mass throughout the host animal lifespan (Montanya et al. 2000). Increase of islet mass in the adult may occur by neogenesis (islet formation from ductal precursor cells), replication of existing islet cells, and $\beta$-cell hypertrophy (for review, see Bonner-Weir 1994).

\section{Selected transcription factors essential for pancreas development and function}

Ipf1/Pdx1 is a member of the ParaHox group of homeodomain transcription factors expressed in endoderm (Brooke et al. 1998; Coulier et al. 2000) and is required for pancreas development in mice and humans (Jonsson et al. 1994; Offield et al. 1996; Stoffers et al. 1997b). Embryonic tissue recombination studies suggest that there is an endodermal cell-autonomous requirement for Ipf1/ $\mathrm{Pdx} 1$ to promote competence to growth signals from pancreatic mesenchyme (Ahlgren et al. 1996). In postnatal animals, Ipf1/Pdx1 is expressed in pancreatic $\beta$-cells, and recent studies suggest that $\operatorname{Ipf} 1 / \mathrm{Pdx} 1$ is required for functions in the mature $\beta$-cell (Stoffers et al. 1997a; Ahlgren et al. 1998; Dutta et al. 1998). Thus, Ipf1/Pdx1 serves distinct roles at different developmental stages, a property of several signaling genes described in this review. Mice deficient for the homeodomain transcription factor Hlxb9 fail to express $I p f 1 / P d x 1$ in the dorsal pancreas, resulting in dorsal pancreatic agenesis (Harrison et al. 1999; Li et al. 1999). In the remaining ventral pancreas of Hlxb9-deficient animals, islet malformations were observed, suggesting essential functions for Hlxb9 in islet cell development. Studies have shown that the DNAbinding activity of Hox or ParaHox gene products like Ipf1/Pdx1 is regulated by Pbx1 and Meis, TALE-class homeodomain proteins (Peers et al. 1995; Swift et al. 1998) that are homologs of the Drosophila extradenticle (exd) and homothorax (hth) gene products. Pancreatic defects in Pbx1-deficient animals (S.K. Kim, L. Selleri, J.S. Lee,
Y. Jacobs, and M.L. Cleary, in prep.) resemble those resulting from inactivation of Islet-1, a LIM homeodomain transcription factor required for islet cell differentiation and dorsal pancreatic exocrine development (Ahlgren et al. 1997).

\section{Specifying the pancreas anlage}

During embryogenesis, organs develop in a stereotyped sequence along the respiratory and gastrointestinal tracts. This organization is accomplished through the temporal and spatial regulation of signaling pathways that specify and thereby separate the distinct organ anlagen. Many endoderm-derived organs, including lungs, trachea, thyroid, liver, and gallbladder, develop from a ventral portion of the gut. In contrast, the first sign of pancreas morphogenesis in birds and mammals is a dorsal evagination of the foregut caudal to the stomach anlage. Subsequently, a ventral bud develops adjacent to the liver diverticulum. This ventral bud translocates to the dorsal side during gut rotation to form the mature pancreas. In some species, including humans, this is accomplished by fusion of the dorsal and ventral lobes (Slack 1995). Therefore, pancreas development requires specification of the pancreas anlage along both anteriorposterior (AP) and dorsal-ventral (DV) axes.

\section{Notochord-endoderm interactions in pancreas development}

Early experiments revealed that induction of dorsal pancreas development occurs at the 6-13-somite stage in mice and chicks (Wessells and Cohen 1967; Spooner 1970; Dieterlen-Lièvre and Beaupain 1974; Sumiya and Mizuno 1987) when dorsal endoderm contacts notochord (Wessells and Cohen 1967; Pictet and Rutter 1972). Embryonic manipulations in chicks have revealed that premature separation of notochord from endoderm abolishes expression of pancreatic marker genes, while coculture of isolated notochord with endodermal epithe- 
lium restores marker expression. Interestingly, the notochord is only capable of inducing pancreas marker expression in anterior but not posterior endoderm, indicating that the endoderm is already prepatterned at this early stage (Kim et al. 1997b). Studies by Wells and Melton (2000) support this prepatterning hypothesis by showing that factors produced in the overlying mesoderm and ectoderm regionally specify endoderm at the late gastrulation stage.

At the time when pancreas formation is initiated, the notochord secretes a variety of potent inducing molecules (Fig. 1A), including the TGF- $\beta$ family member activin- $\beta$ B, and FGF2. Tissue culture experiments with chick embryos have revealed that both ligands can mimic the notochord effect and induce transcription of pancreatic marker genes in isolated endoderm. Isolated notochord, or purified activin, and FGF activate pancreatic gene expression by repressing expression of Sonic hedgehog (Shh), a secreted protein of the Hedgehog family, in dorsal prepancreatic epithelium (Hebrok et al. 1998). The notochord also produces Shh and induces $S h h$ expression in overlying floorplate cells in the neural tube. The apparent embryologic paradox that notochord both induces and represses Shh expression may be explained by evidence that dorsal endoderm and ventral neural tube have different competence for Hedgehog, FGF, and TGF- $\beta$ signals (Briscoe et al. 2000). For example, expression of activin receptor IIB is detected in chick endoderm and dorsal neural tube but not ventral neural tube (Stern et al. 1995) just before pancreatic morphogenesis.

\section{Endodermal Shh repression permits pancreas development and governs anterior-posterior gastrointestinal pattern}

Recent studies have established roles for activin and Hedgehog signaling in patterning foregut gene expression and organogenesis in mice. Mutations of type II activin receptors ActRIIA and ActRIIB were shown to disrupt the development of the pancreas and other foregutderived organs like stomach and spleen (Kim et al. 2000). The pattern of organ malformations in these mutants was consistent with an anterior transformation of organ fates in the foregut and corresponded with AP shifts in expression of genes including Shh and Isl1. The role of Shh in establishing pancreatic development has also been tested extensively. In the midgestational mouse embryo, Shh is expressed in nearly all epithelial cells lining the alimentary canal (Echelard et al. 1993; Bitgood and McMahon 1995; Ramalho-Santos et al. 2000), with the important exception that Shh is excluded from Rathke's pouch (the oral epithelial primordium of the anterior pituitary) and from pancreatic epithelium (Apelqvist et al. 1997; Hebrok et al. 1998, 2000; Treier et al. 1998; Fig. 1). In mice and chicks, ectopic expression of Shh in embryonic pancreatic epithelium results in loss of pancreas marker expression and transformation of pancreatic mesenchyme into gut mesoderm (Apelqvist et al. 1997; Hebrok et al. 1998). Inhibition of Hedgehog signal- ing, by incubation of isolated foregut endoderm with antibodies directed against Shh, induces pancreatic gene expression (Hebrok et al. 1998). Thus, in both pancreas and pituitary development, spatially restricted Shh expression creates molecular boundaries in epithelium, and the absence of Shh provides a permissive condition leading to appropriate organogenesis along the embryonic AP axis.

AP patterning in mesoderm and ectoderm is regulated by spatially restricted expression of Hox transcription factors (Krumlauf 1994) that are encoded in defined genomic regions, the Hox clusters. In the hindgut, endodermal Shh activates expression of Hox genes in overlying mesoderm (Roberts et al. 1995, 1998). However, few Hox genes are expressed in endodermally derived epithelium, and mutations in Hox genes have not yet been shown to result in AP transformations of endoderm-derived organs in vertebrates (for review, see Grapin-Botton and Melton 2000). A set of Hox-related genes that are expressed in endoderm make up the ParaHox cluster, first identified in Amphioxus (Brooke et al. 1998). The expression of $I p f 1 / P d x 1$, a ParaHox member, is not restricted to pancreatic tissue, and dorsal and ventral bud outgrowth is initiated in $P d x 1$ mutant animals /Offield et al. 1996), suggesting that other factors are required to specify the pancreas anlage. A potential candidate is Hlxb9, a homeobox transcription factor that is expressed in the dorsal bud before $I p f 1 / P d x 1$ and whose function is required for dorsal but not ventral bud morphogenesis (Harrison et al. 1999; Li et al. 1999). Expression of Shh and Indian hedgehog (Ihh) in the pancreas is not affected in Hlxb9 mutants (Li et al. 1999), but it remains to be determined if Hlxb9 expression is regulated by endodermal Hedgehog signals. For example, it would be interesting to see if Hlxb9 expression is altered in mice that misexpress Sonic hedgehog in dorsal pancreas epithelium (Apelqvist et al. 1997).

\section{Establishment of the dorsal and ventral pancreatic anlagen}

While some progress has been made in understanding the signaling pathways that regulate early stages of dorsal pancreas development, much less is known about the development of the ventral pancreas. The notochord does not touch lateral endoderm, the part of the gut that gives rise to the ventral pancreas. Nevertheless, Shh expression is repressed in this prepancreatic lateral endoderm (Kim et al. 1997b). During dorsal pancreas formation, Shh remains excluded from dorsal pancreatic tissue even after notochord and endoderm are separated by the fusion of the paired dorsal aorta (Apelqvist et al. 1997; Kim et al. 1997b; Hebrok et al. 1998). Thus, there may be separate mechanisms to initiate and then to maintain Shh repression in dorsal pancreatic endoderm. It will be interesting to determine if similar mechanisms are responsible for Shh repression in the ventral pancreas.

In contrast to the fusion of initially separate ventral and dorsal pancreatic anlagen, the splenic and dorsal pancreatic primordia initially overlap, then separate (Fig. 
1B). The spleen forms in dorsal mesenchyme overlying the distal stomach and dorsal pancreas, and DieterlenLièvre (1970) reported that endoderm from the dorsal pancreas anlage can direct hematopoiesis and vasculogenesis (characteristic of spleen development) in heterologous mesenchyme. Because notochord signals appear to influence the properties of this endoderm, it will be interesting to test if notochord signals may influence splenic development. Recent reports have demonstrated common genetic requirements for pancreas and spleen development. In mice expressing ectopic Shh in pancreatic epithelium, the spleen is absent and pancreatic epithelium and mesenchyme adopt intestinal fates (Apelqvist et al. 1997). Thus, normal pancreas and spleen morphogenesis require $S h h$ repression in posterior foregut epithelium. Likewise, mice deficient for the type II activin receptor ActRIIB have both severe hyposplenism and pancreatic hypoplasia (Oh and Li 1998; Kim et al. 2000). Examination of mice deficient for the transcription factor p48 (Krapp et al. 1998) provides dramatic evidence that molecular mechanisms also exist to establish appropriate boundaries between pancreas and spleen. In mice lacking $\mathrm{p} 48$, there is no detectable exocrine pancreas development, but cells expressing insulin and other pancreatic endocrine cell gene products are found in the remaining spleen. Splenic malformations or agenesis occur in mice with mutations in Hox11 (Roberts et al. 1994), Wilms tumor supressor gene 1 (wt1; Herzer et al. 1999), Bapx1 (Lettice et al. 1999; Tribioli and Lufkin 1999), and capsulin (Lu et al. 2000). Pancreatic malformations in mice deficient for these genes have not been reported, but overlapping embryologic and genetic requirements for pancreas and spleen development invite close (re)examination of these genes for possible roles in pancreas formation.

\section{Intercellular signals govern pancreas cell fate}

The ratio of exocrine to endocrine cell mass is approximately 100:1 in mice and humans but varies in other species, suggesting that genetic mechanisms regulate this ratio. What are the molecular signals responsible for correct apportioning of pancreatic cell fates? Early studies (Golosow and Grobstein 1962; Wessells and Cohen 1967; Pictet and Rutter 1972) showed that pancreatic exocrine development required mesenchymal signals that can be replaced by cell-free extracts (Golosow and Grobstein 1962). Conclusions about the role of cell interactions in endocrine differentiation were limited in these studies, however, partly because of their reliance on morphologic markers of development. Later studies using molecular markers of endocrine and exocrine cells showed that removal of pancreatic mesenchyme impairs pancreatic exocrine development but promotes endocrine cell development (Rutter et al. 1978; Gittes et al. 1996; Miralles et al. 1998b). These data support the hypothesis that epithelial-mesenchymal interactions regulate the appropriate balance of endocrine and exocrine development. Here we focus on recent experiments suggesting that intercellular signaling through the TGF- $\beta$, Notch, and Hedgehog pathways are crucial for appropri- ate specification of endocrine and exocrine pancreas cell fates (Fig. 3).

\section{TGF- $\beta$ signaling}

TGF- $\beta$ signaling is a major regulator of pancreatic endocrine and exocrine cell fates. TGF- $\beta$ signaling components (for review, see Massagué and Chen 2000) including the TGF- $\beta$ ligands activin and TGF- $\beta 1$; their respective receptors; ligand antagonists including follastatin, noggin, and gremlin; and intracellular Smads like Smad2 and Smad4 are expressed in embryonic pancreas epithelium and mesenchyme (Ogawa et al. 1993; Feijen et al. 1994; Furukawa et al. 1995; Verschueren et al. 1995; Manova et al. 1995; Crisera et al. 2000; Tremblay et al. 2000; J. S. Lee and S. K. Kim, unpubl.). In vitro exposure of embryonic mouse pancreas to activin or TGF- $\beta 1$ promotes development of endocrine cells, particularly $\beta$ cells and PP cells (Sanvito et al. 1994), and disrupts epithelial branching and acinar formation (Ritvos et al. 1995). Follistatin, a known antagonist of TGF- $\beta$ signals, including activins, promotes embryonic exocrine cell differentiation and reduces differentiation of endocrine cells (Miralles et al. 1998b). Thus, TGF- $\beta 1$ and activin may promote endocrine cell development.

Three recent studies of activin receptor function in vivo support these earlier in vitro studies. ActRIIA and ActRIIB are broadly expressed in the midgestation mouse embryo, including in the pancreatic epithelium (Manova et al. 1995; Verschueren et al. 1995), and later are expressed in adult islets (Yamaoka et al. 1998; S.K. Kim, unpubl.). Pancreatic expression of a dominant-
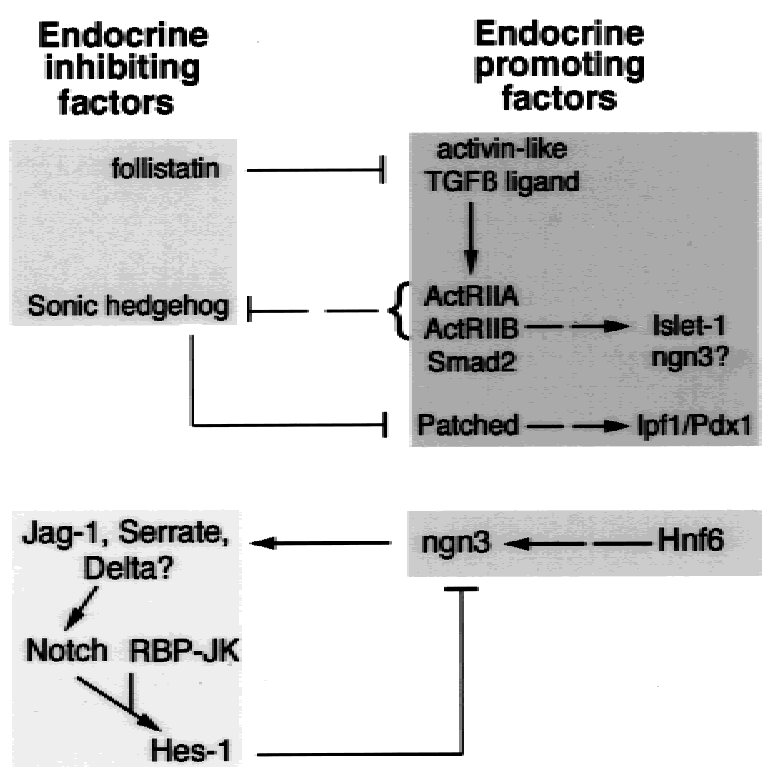

Figure 3. Signaling molecules that promote exocrine or endocrine cell differentiation in pancreas development. Established interactions between molecules indicated by solid lines with arrows $(\downarrow)$ denoting stimulation and blunt lines $(\perp)$ denoting inhibition of activity. Indirect interactions indicated by dashed lines, with arrowheads denoting stimulation and blunt lines repression of target gene expression. 
negative type II activin receptor (dnActRIIA) in transgenic mice results in islet hypoplasia (Yamaoka et al. 1998; Shiozaki et al. 1999|. Recent analysis of mice harboring null mutations in type II activin receptors ActRIIA and ActRIIB shows that islet cell differentiation is likely regulated by activin receptor-mediated TGF- $\beta$ signaling (Kim et al. 2000).

How does type II activin receptor-mediated signaling regulate pancreatic endocrine development? Previous studies demonstrate that ligand-bound ActRIIA and ActRIIB form a protein complex with type I receptors and a restricted subset of intracellular R-Smad targets, including Smad2 and Smad3. R-Smads, phosphorylated by type I receptor kinases, modulate the activity of hetero-oligomeric transcription factor complexes that include Smad4 (for review, see Wrana 2000). Identification of TGF- $\beta$ ligands, type I receptors, and R-Smads that function with type II activin receptors to promote endocrine cell growth is therefore the focus of considerable effort. Studies of mice heterozygous for the Smad2mh1 null allele (Nomura and Li 1998) reveal that Smad2 haploinsufficiency results in several embryonic and adult endocrine pancreatic defects (Osborne et al. 2000).

Thus, these studies provide evidence for regulation of crucial aspects of pancreas development by TGF- $\beta$ signaling pathways, but many questions remain unanswered. Additional receptors, ligands, and intracellular signaling components require identification. Within the framework of epithelial-mesenchymal interactions, it remains unclear which cells are transmitting and which cells are receiving TGF- $\beta$ signals. To address this question will require better characterization of the cellular expression patterns of TGF- $\beta$ signaling components and in vitro tissue recombination experiments to test if pancreas phenotypes resulting from specific mutations are cell autonomous or cell nonautonomous (Ahlgren et al. 1996).

\section{Notch signaling}

Several recent studies in mice suggests that the Notch signaling pathway regulates pancreatic endocrine and exocrine cell fate (Apelqvist et al. 1999; Jensen et al. 2000a,b; Gradwohl et al. 2000; Schwitzgebel et al. 2000; Jacquemin et al. 2000). Notch signaling in Drosophila and mammalian neuronal differentiation (for review, see Anderson et al. 1997; Baker 2000) provide valuable paradigms for understanding some of the pancreatic phenotypes resulting from perturbed Notch signaling. In neural development, expression of neurogenin genes leads to neural precursor cell production of extracellular ligands like Delta, Serrate, or Jagged that activate Notch receptors on adjacent cells (Fig. 3). In concert with the DNAbinding protein $\mathrm{RBP}-\mathrm{J} \kappa$, an intracellular portion of the activated Notch receptor promotes transcription of hairy/enhancer-of-split genes (Hes) in these adjacent cells. Hes genes encode bHLH factors that repress expression of neurogenin and other target genes, thereby preventing neuronal differentiation in cells adjacent to developing neuroblasts (lateral specification).
Within or adjacent to epithelium of the embryonic pancreas, individual cells and small cell clusters express ngn3, a member of the neurogenin family (Apelqvist et al. 1999; Gradwohl et al. 2000; Jensen et al. 2000b; Schwitzgebel et al. 2000). ngn3 expression peaks at $15.5 \mathrm{dpc}$, just before the formation of recognizable islets at $17 \mathrm{dpc}$, and is undetectable later in the adult pancreas. Mice deficient for Delta-like ligand 1 (D11-1) or RBP-JK had accelerated differentiation of pancreatic epithelial cells expressing ngn3 or glucagon (Apelqvist et al. 1999). Hes1-deficient mice simultaneously had precocious development of endocrine cells, and exocrine cell defects, including acinar cell apoptosis and hypoplasia (Jensen et al. 2000b).

The timing and levels of ngn3 expression appear to be critical for normal pancreatic cell differentiation. Misexpression of $n g n 3$ from $I p f 1 / P d x 1$ promoter elements produced endocrine and exocrine cell phenotypes similar to those in Hes-1 deficient mice (Apelqvist et al. 1999; Schwitzgebel et al. 2000). Mice deficient for hepatic nuclear factor $6(h n f 6)$ had reduced $n g n 3$ expression, distorted hypoplastic islets, and impaired glucose homeostasis (Jacquemin et al. 2000). Pancreatic endocrine cells fail to form, and exocrine cell secretory granules accumulate in ngn3-deficient mice (Gradwohl et al. 2000). Thus, ngn3 is essential for normal endocrine and exocrine differentiation, consistent with the possibility that ngn3-expressing cells either govern pancreatic cell fate and/or are themselves precursors of both islet and acinar cells. Herrera (2000) has demonstrated that cre-loxP methods can be adapted to permanently mark and follow cell lineages in the pancreas. Analogous genetic marking of ngn3-expressing cells might provide direct evidence that such cells are precursors of both endocrine and exocrine cells.

Data from these recent studies fulfill several predictions of a model for pancreatic cell fate determination based on the lateral specification hypothesis. However, several specific aspects of this model of pancreatic Notch signaling have not yet been conclusively demonstrated. It is not known if, as predicted by the lateral specification model, ngn3-expressing cells express D111 or other ligands and if adjacent ductal epithelial cells expressing Notch receptor(s) increase Hes gene transcription and repress ngn3 expression. Detailed analysis of pancreatic expression patterns of Notch signaling components (see Lammert et al. 2000) and improvements in appropriate molecular probes might address this issue. Observations on the distribution of pancreatic- and entero-endocrine cells are not well explained by lateral specification models. The well-spaced, stereotyped position of proneural cells in Drosophila is consistent with lateral specification models. Pancreatic ngn3-expressing cells, however, form multicellular clusters within and adjacent to embryonic ductal epithelium (Jensen et al. 2000b; Gradwohl et al. 2000). Drosophila mutants deficient for neurogenic genes like $E(s p l)$ develop increased numbers of clustered neuroblasts (Cabrera 1990; Skeath and Carroll 1992). Jensen et al (2000b) have observed that increased numbers of entero-endocrine cells in mice deficient for Hes1 do not cluster but remained scattered. These workers 
have suggested, therefore, that Hes1 activity may prepattern endoderm.

While Notch signaling may function in the embryonic pancreas to regulate cell fate, what about in juvenile and adult animals? Four groups (Apelqvist et al. 1999; Gradwohl et al. 2000; Jensen et al. 2000b; Schwitzgebel et al. 2000) have reported that ngn3 expression is not detectable in the postnatal pancreas. This is somewhat puzzling, especially as it has been reported that there is extensive postnatal islet neogenesis in rodents (for review, see Bonner-Weir 1994; Slack 1995). Further characterization of pancreatic gene expression in adult animals would be helpful, but the current evidence raises the possibility that Notch signaling may not regulate islet formation or neogenesis in adult animals. Thus, unlike in the embryo where Jensen et al. (2000b) have stated that ngn3-expressing cells represent "the immediate precursors for the endocrine cells," the situation in the postnatal animal may be different. Instead, a $P d x 1$-expressing stem cell, which no longer produces ngn3, may be the source for differentiated endocrine cells in the adult.

Studies of Notch signaling in pancreas provide evidence that this genetic pathway is important for regulating the level and timing of pancreatic precursor cell production in development. Further studies are required, however, before we can harness this new knowledge to promote normal islet and $\beta$-cell growth in vitro or in vivo. Notch1 inactivation, specifically in mouse pancreatic endocrine cells, results in increased islet cell mass, but islet cellular distribution in these mice is abnormal (P. Herrera and F. Radtke, in prep.). Hes1 inactivation (Jensen et al. 2000b) or forced misexpression of ngn3 from $I p f 1 / P d x 1$ promoter elements in mice (Apelqvist et al. 1999; Schwitzgebel et al. 2000) results in exocrine cell hypoplasia and $\alpha$-cell hyperplasia, but not $\beta$-cell or islet hyperplasia. Thus, it may be crucial to identify the signal(s) that govern the proliferation of ngn3-expressing cells and that direct their postmitotic differentiation.

\section{Hedgehog signaling}

Pancreatic organogenesis is regulated by the interaction of distinct signaling pathways that promote or restrict morphogenesis and cell differentiation. Activin signaling permits pancreas development by repressing expression of Sonic hedgehog (Fig. 3). Before pancreatic morphogenesis, repression of Sonic hedgehog in posterior foregut endoderm prevents intestinal differentiation (Apelqvist et al. 1997) and promotes the pancreatic fate (Hebrok et al. 1998). In addition to this role in organ fate, recent studies suggest that Hedgehog signaling pathways regulate embryonic pancreas cell fates (Hebrok et al. 2000).

While Shh is not detectable in embryonic pancreas or purified adult islets, both Ihh and Desert Hedgehog (Dhh), as well as Patched (Ptc), a Hedgehog receptor, are expressed in the developing pancreas and adult islets. In addition to characteristic pancreatic malformations, the relative number of pancreatic insulin- and glucagon-expressing cells in $\mathrm{Ih}^{-/-}$-deficient embryos is marginally increased, compared to wild-type sibling controls (He- brok et al. 2000). Endocrine cell overgrowth is more severe in embryos deficient for Shh. A fourfold relative increase in numbers of pancreatic insulin- and glucagonexpressing cells and a sevenfold increase in posterior stomach cells expressing glucagon is observed in Shh mutants. Thus, like Hes1-deficient mice (Jensen et al. 2000b; Schwitzgebel. 2000), Shh ${ }^{-1-}$ mice have an inappropriate increase of pancreatic and enteric glucagon-expressing cells. These results suggest that Shh activities are necessary for limiting differentiation of pancreaticand entero-endocrine cells, similar to the proposed role for Notch signaling in pancreas. Do other Hedgehog ligands have similar roles in the pancreas? Shh and Ihh have similar structures, posttranslational modification, and patterns of endodermal expression, but a recent study demonstrates nonredundant or antagonistic functions for Shh and Ihh during stomach and intestinal development (Ramalho-Santos et al. 2000). Therefore, it will be important to determine if the signaling activities of Ihh or Dhh differ from those of Shh in the embryonic and postnatal pancreas.

How can deficiency for Shh perturb endocrine cell development in the pancreas, an organ that does not express this gene? One likely possibility is that Shh inactivation perturbs signals between pancreas and adjacent organs that normally express Shh, including notochord, gallbladder, liver, stomach, and duodenum. Shh activity produced by these adjacent organs may directly limit the extent of endocrine cell differentiation in pancreas. Alternately, Shh expression in these adjacent tissues may elicit other signals (perhaps capable of greater diffusion than Shh) that limit pancreatic- and entero-endocrine development. Similar models have been proposed for Shh function in establishing regionalized dorsal-ventral cell fates in the developing vertebrate neural tube (Briscoe et al. 2000).

Hedgehog signals like Shh and Ihh bind the receptor protein encoded by Patched, which is expressed in embryonic pancreas epithelium and mesenchyme (Hebrok et al. 1998) and later in mature islets (Hebrok et al. 2000). Biochemical and genetic studies demonstrate that Hedgehog activity represses Ptc functions (for review, see Goodrich and Scott 1998). Given that Hedgehog activity normally limits pancreatic endocrine cell development, Ptc inactivation would be expected to result in impaired pancreatic endocrine development and function. Before embryonic death at $\sim 9.5 \mathrm{dpc}, \mathrm{Ptc}^{-/-}$mutants fail to express $P d x 1$ or glucagon in the dorsal pancreatic anlage (Hebrok et al. 2000). Ptc $^{+/-}$adults have malformed islets and impaired glucose tolerance, consistent with the possibility that Ptc haploinsufficiency results in impaired pancreatic endocrine function, in addition to other phenotypes (Goodrich and Scott 1998; Milenkovic et al. 1999). Elucidating specific functions of Ptc in pancreas may require pancreas-specific Ptc inactivation.

\section{Integration of distinct intercellular signaling activities}

Hedgehog, TGF- $\beta$, and Notch signaling are necessary for normal pancreatic and enteroendocrine cell develop- 
ment (Hebrok et al. 2000; Kim et al. 2000; Jensen et al. $2000 \mathrm{~b})$. How might these pathways interact to regulate pancreas development? Prior studies have suggested that Hedgehog signaling regulates Notch signaling. Hedgehog signals regulate $n g n 1$ expression in zebrafish neural plate (Blader et al. 1997), and Hedgehog signals induce expression of the ligand Serrate, an activator Notch, during cell fate determination in segmenting Drosophila epidermis (Alexandre et al. 1999). Endocrine cell expansion in mice harboring mutations in Shh or Hes1 suggest that the Hedgehog and Notch pathways also function in dependent or parallel pathways in embryonic pancreas.

We have described studies of chicks and mice suggesting that TGF- $\beta$ signals regulate the expression of Hedgehog signals like Shh in the developing foregut (Hebrok et al. 1998; Kim et al. 2000). TGF- $\beta$ pathways also regulate expression of Serrate, Delta, and Fringe in the segmenting Drosophila leg (Rauskolb and Irvine 1999), and a recent study provides evidence that TGF $\beta$ signaling modulates Notch signaling in the pancreas (Osborne et al. 2000). ngn3 expression normally peaks in pancreatic periductal epithelial cells at embryonic day 15.5 (E15.5) and decreases thereafter (Gradwohl et al. 2000; Schwitzgebel et al. 2000). In the pancreas of Smad2 mutants, there is both abnormal persistance of (peri)ductal cell ngn3 expression throughout gestation and severely decreased expression of Hes1 (A. Ko and S. Kim, unpubl.). Thus, it appears likely that TGF- $\beta$ signaling may regulate expression of Notch components in the developing pancreas.

\section{Pancreatic and islet morphogenesis}

FGF, activin, and Hedgehog signaling pathways govern pancreas morphogenesis

Many pancreas diseases are associated with defects in pancreatic architecture, but the molecular mechanisms underlying these defects had not been described until recently. Several studies provide evidence that signaling pathways governing pancreatic cell fate also regulate the morphogenesis of pancreatic structures. FGF signaling regulates proliferation of endocrine and exocrine cell types (Nguyen et al. 1996; Le Bras et al. 1998; Miralles et al. 1999), and inhibition of FGFR2 signaling, through expression of a dominant-negative form of the receptor, results in a significant reduction of acinar cells and loss of islets (Celli et al. 1998). While downstream target genes of FGF signaling in embryonic pancreatic tissue have not been identified, the phenotype caused by inhibition of FGF signaling is reminiscent of the malformations observed in mice lacking the basic helix-loophelix protein $\mathrm{p} 48$. Loss of $\mathrm{p} 48$ activity results in the complete loss of exocrine cells and the disruption of islet shape. Remnants of the islets are found in the spleen (Krapp et al. 1998), suggesting that the pancreatic exocrine matrix provides essential clues for the spatial organization of developing islets.

Signaling through the activin and Hedgehog pathways also controls pancreas size and shape. Loss of activin signaling in mice carrying targeted mutations in the type II activin receptors A and B leads to Shh de-repression, resulting in anomalous association of pancreatic tissue with adjacent intestine and severe hypoplasia of the dorsal pancreas and spleen (Kim et al. 2000). Similar phenotypes are found in transgenic mice ectopically expressing Shh in the pancreatic region (Apelqvist et al. 1997).

\section{Animal models of congenital pancreatic malformations}

Misregulation of Hedgehog signaling in the mouse gastrointestinal tract is associated with a variety of congenital malformations including duodenal stenosis, imperforate anus, and defective enteric ganglion development (Litingtung et al. 1998; Ramalho-Santos et al. 2000). Ihh or Shh inactivation has also been shown to cause overgrowth of ventral pancreatic tissue, a phenotype strikingly similar to an uncommon human disorder known as annular pancreas (Hebrok et al. 2000; Ramalho-Santos et al. 2000; Table 1). Annular pancreas in humans and in late-gestational mice deficient for Ihh or Shh is characterized by a band of pancreatic tissue that constricts the duodenum (Hill and Lebenthal 1993). Diverse hypotheses have been proposed to explain this disorder (Baldwin 1910; Lecco 1910; Hill and Lebenthal 1993), none of which are supported by experimental evidence. Results from studies of Ihh and Shh mutant embryos have revealed at least two distinct malformations in the ventral pancreas before formation of a complete annulus. These include an asymmetric lateral branching of the ventral duct and dichotomous (symmetric) branching of the ventral pancreas (Hebrok et al. 2000).

Pancreas divisum is another, more common congenital defect of dorsal and ventral pancreatic fusion, which is associated with a high percentage of chronic, relapsing pancreatitis in humans (Cotton 1980). In this disorder, the dorsal and ventral pancreatic ductal systems fail to fuse properly. Ventral pancreatic ductal malformations have been described in mice heterozygous for null alleles of Shh and Ihh (Hebrok et al. 2000). Inappropriate fusion of ventral and dorsal pancreatic ducts is also observed in mice deficient for Smad2 (A. Zhang and S. Kim, unpubl.). Thus, defects in Hedgehog or TGF- $\beta$ signaling may promote pancreas divisum.

Hedgehog signaling can be pharmacologically inhibited with alkaloid compounds derived from plants of the Veratrum species (Cooper et al. 1998); for example, inhibition of midline Shh signaling with cyclopamine phenocopies malformations observed in mice (Chiang et al. 1996) and humans deficient for Shh (Belloni et al. 1996). Inhibition of Hedgehog signaling in chick embryos treated with cyclopamine leads to heterotopic pancreas formation, particularly in stomach and duodenum (Kim and Melton 1998). Stomach, duodenum, and jejunum are also the most common sites of pancreatic heterotopia in humans (Hill and Lebenthal 1993), raising the possibility that Hedgehog signaling defects may underlie some forms of this disorder in man. 
Table 1. Human diseases and candidate disease genes identified by embryologic studies

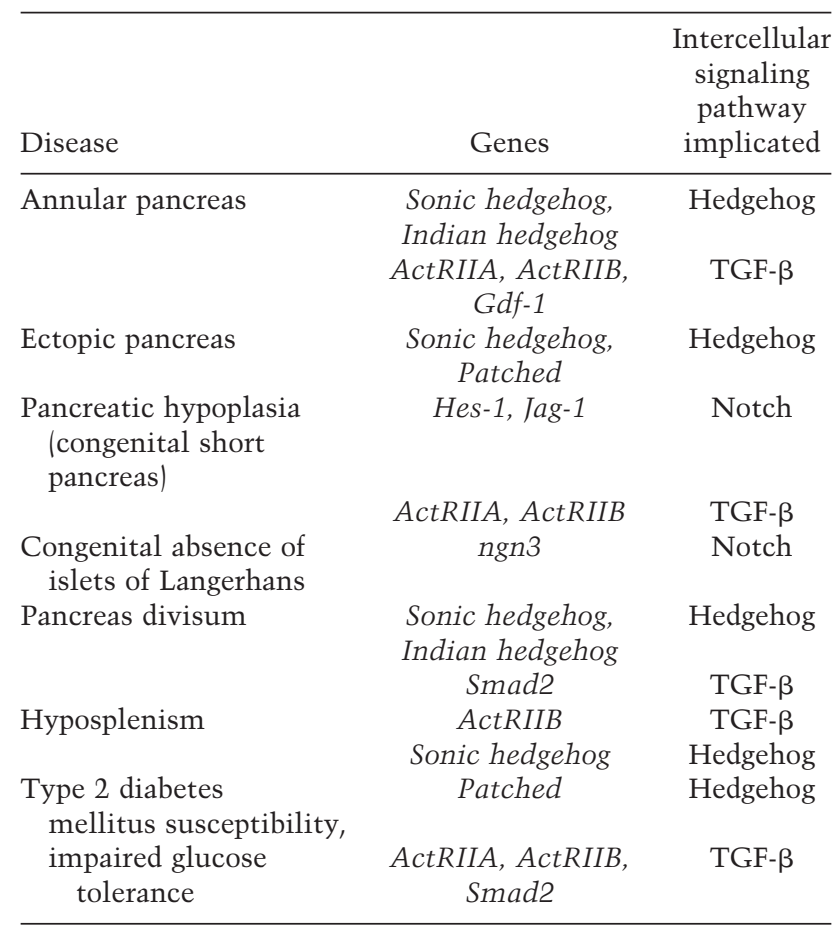

Perturbation of Sonic hedgehog activity and Patched expression in studies with chick embryos generated ectopic pancreas (Kim and Melton 1998). Evidence for roles of genes in the other listed pancreatic defects were derived from genetic studies of mice. More information on the mouse and chick studies pertaining to the genes and phenotypes described in this Table can be found on Seung Kim's laboratory home page (http://seungkimlab.stanford.edu).

\section{Regulation of islet size}

Optimal organ function requires a match between organ size and physiologic demands of the host organism. Transplantation studies, for example, emphasize that renal, cardiac, or pancreas function is optimized when the mass of the donor organ fits the mass of the recipient (Nicholson et al. 2000). Mismatching organ and host size can be lethal, yet little is known about the mechanisms that achieve appropriate relative organ size. Islet size and number must match host needs to maintain proper glucose homeostasis, but the mechanisms that match islet size and number to body mass are not completely understood. Recent studies have shown that the antagonistic effects of Hedgehog and activin signaling within pancreas and adjacent organs regulates islet size and function. Inhibition of Hedgehog signaling in chick embryos treated with cyclopamine resulted in hyperplastic, clustered islets (Kim and Melton 1998). Inappropriate clustering of islets near ducts was also observed in $\mathrm{Shh}^{-/-}$and $S h h^{-1-}$ Ih $^{+/-}$mutants (Hebrok et al. 2000).

Recent studies show that islet size and function may be determined by the extent of activin receptor-mediated TGF- $\beta$ signaling (Kim et al. 2000). While ActRIIA ${ }^{+/-}$, ActRIIA $^{-/-}$, and ActRIIB $^{+/-}$animals appear to have normal pancreatic development and function, ActRIIA ${ }^{+/-} \mathrm{B}^{-/-}$,
ActRIIB $^{-/-}$, and ActRIIA ${ }^{+/-} \mathrm{B}^{+/-}$animals have hypoplastic pancreatic islets, with normal exocrine development. ActRIIA $^{-/-}$mice had normal glucose tolerance tests. In contrast, ActRIIB ${ }^{-/}$animals had abnormal peak glucose levels during glucose tolerance tests. Islet size was most severely reduced in ActRIIA ${ }^{+/-} \mathrm{B}^{+/-}$animals, and these also had the most impaired glucose tolerance. Thus, the severity of impaired glucose tolerance and the degree of islet hypoplasia depended on the type and degree of activin receptor inactivation. Are these postnatal phenotypes the result of developmental defects in foregut patterning or an indication that activin signals have distinct postembryonic roles in pancreatic islet function? It will be necessary to perturb activin signaling specifically in postnatal animals to test this hypothesis. However, insulin promoter-directed expression of a dominant-negative activin receptor transgene specifically in mouse islets also results in islet hypoplasia (Yamaoka et al. 1998), consistent with the possibility that activin signals may have separate roles in embryonic foregut patterning and embryonic islet formation. Follistatin, an activin antagonist, has been shown in cell culture experiments to limit pancreatic endocrine differentiation and islet formation (Miralles et al. 1998b). It will be interesting to test if inhibition of follistatin or ectopic expression of activin signaling components is sufficient to induce endocrine cell differentiation and formation of islet structures in endodermal precursor cells.

\section{Matrix metalloproteinases regulate islet formation}

Islets are generated in a multistep process that involves differentiation of progenitor cells from pancreatic ductal epithelium, migration of these precursors through the basal membrane into the surrounding mesenchyme, and subsequent association of hormone-producing cells into mature islets (Fig. 2). Mouse aggregation chimaera studies have demonstrated that islets form by mixture of endocrine cells derived from independent precursor cells (Deltour et al. 1991). The migration of islet precursor cells is partially controlled by matrix metalloproteinases (MMP; Miralles et al. 1998a), a large family of enzymes that degrade extracellular matrix proteins, including collagens, gelatins, fibronectin, and laminins (Werb 1997). Previous studies have demonstrated that MMP's are required for branching morphogenesis of several organs and that they govern the migration of a variety of different cell types (for review, see Vu and Werb 2000). Two proteases, MMP2 and MMP9, are expressed during pancreas development, and inhibitors of MMP function interfere with islet morphogenesis in isolated pancreatic epithelia. MMP activity in islets may be regulated by TGF- $\beta$ signals (Miralles et al. 1998a).

Further support for a critical role of MMP's during islet morphology and $\beta$-cell development comes from studies in epidermal growth factor-receptor (EGFR) mutants. Signaling through the EGFR induces MMP secretion, and the level of activated MMP's is reduced in pancreata of EGFR mutant mice (Miettinen et al. 2000; van der Zee et al. 1998). While gross pancreatic morphology in these 
mice appears normal, epithelial branching is clearly decreased, and islets remain in close proximity to the pancreatic ducts. These findings suggest that matrix degradation and remodeling is crucial for epithelial morphogenesis and migration of endocrine precursors. Transgenic mice ectopically expressing EGF in $\beta$-cells develop dramatic morphological changes in islet structure that worsen with age. Islets are irregularly shaped and larger compared to age-matched control animals; however, impairment of islet function or glucose homeostasis was not observed (Krakowski et al. 1999a).

\section{Roles of extracellular matrix and cell adhesion in regulating islet morphogenesis}

Previous studies have demonstrated that extracellular matrix (ECM) proteins (Gittes et al. 1996) or inhibition of cell adhesion molecules like Ep-CAM (Cirulli et al. 1998) affect endocrine cell differentiation. Once islet cells form, evidence suggests that islet cell-ECM interactions and cell-cell interactions also coordinate subsequent islet cell aggregation and sorting. Until recently, little was known about the mechanisms that guide migration of islet precursors. Previous studies had suggested that organization of endocrine cell types into proper islet structures could be regulated by integrins, transmembrane receptors that are expressed in islet and $\beta$-cells and bind to ECM proteins (Kantengwa et al. 1997; Streuli 1999). Support for this hypothesis comes from a recent study by Cirulli et al. (2000), in which $\alpha_{\mathrm{v}} \beta 3$ and $\alpha_{\mathrm{v}} \beta 5$ integrins were shown to mediate adhesion and migration of putative endocrine precursors. Functional significance for these cell-ECM interactions has been demonstrated in studies that address the loss of glucose responsiveness in cultured islet cells. In these studies, isolated islet cells kept on plastic surfaces without matrix support lose their ability to release insulin after stimulation with physiological glucose concentrations. However, glucose responsiveness is restored when islet cells are cultured on extracellular matrix preparations, suggesting that maintenance of $\beta$-cell function is at least partially conferred through binding of integrin receptors (Bosco et al. 2000).

In addition to matrix-to-cell signaling, cell-cell interactions are also required to establish the architecture of individual islets. These interactions are mediated via $\mathrm{Ca}^{2+}$-independent cell adhesion molecules (CAM's) and $\mathrm{Ca}^{2+}$-dependent members of the cadherin family (Rouiller et al. 1991; Dahl et al. 1996; Esni et al. 1999). Members of the cadherin family, including N-, R- and E-cadherin, are expressed in pancreatic islet cells. Inhibition of cadherin function through ectopic expression of a dominant negative E-cadherin protein interferes with embryonic clustering of $\beta$-cells in nascent islets (Dahl et al. 1996). Adhesive properties of non- $\beta$ islet-cells may be regulated by neural cell adhesion molecule (NCAM; Rouiller et al. 1991). Islet architecture in mice lacking NCAM is abnormal, with $\alpha$-cells found throughout the islet core (Esni et al. 1999). In spite of the gross missorting of islet cells in these and other mutant mouse strains (Krakowski et al. 1999a,b), viability and glucose regulation were unaffected. Studies by Meda and others have demonstrated that $\beta$-cells responses to secretogues were promoted by homologous $\beta$-cell to $\beta$-cell contact but decreased by heterologous non- $\beta$-cell to $\beta$-cell contact (for review, see Bosco and Meda 1997). Thus, in mice with malformed islets but normal glucose regulation, islet architecture may be sufficiently preserved to maintain normoglycemia.

\section{Signaling pathways regulating islet growth in adult animals}

Interest in factors that stimulate growth of the pancreas and islets has been considerable since the work of von Mering and Minkowski (1889). Pancreatic growth control in postnatal animals has been reviewed by Hughes (1956), Goss (1978), and more recently, Slack (1995) summarized observations on pancreatic regeneration following pancreatic tissue ablation. In pregnant mice and humans, there is marked $\beta$-cell hyperplasia and increased islet proliferation. Growth hormone, prolactin, placental lactogen, and cellular factors required for transducing the activity of these intercellular signals are implicated in regulating $\beta$-cell responses to gestation, and investigations of these have been reviewed recently (Nielsen et al. 1999). Likewise, there have been recent reviews of other protein regulators of postnatal $\beta$-cell growth and differentiation including hepatocyte growth factor (Hayek et al. 1995) and glucagon-like peptides (Drucker 1998; Holst 1999; Kieffer and Habener 1999). Here we focus on evidence that insulin and TGF- $\beta$ signaling regulate pancreatic islet growth in adult animals.

\section{Diabetes mellitus: the basics}

Pancreatic islet growth is dynamic, responsive to insulin demands of the host (Fig. 4). Insulin demand may reflect host physical activity, obesity, age, gestation, and genetically determined insulin responsiveness. In type 1 diabetes, relentless autoimmune destruction of $\beta$-cells eventually results in absolute insulin deficiency despite, as some evidence suggests, attempts by the pancreas to regenerate islets (Brush 1944; Bonner-Weir 1994). In pathogenesis of $>90 \%-95 \%$ of type 2 diabetes, reduced insulin responsiveness of peripheral tissues like liver, fat, and muscle is the likely initiating step (Martin et al. 1998; Kahn 1994). Overt diabetes results from progressive failure of pancreatic $\beta$ cells to secrete adequate insulin to compensate for resistance (Kahn 2000). In principle, there are at least two mechanisms for pancreatic compensation to increased insulin resistance: first, by increasing $\beta$-cell mass (Fig. 4), and second, by increasing the glucose-stimulated insulin secretory efficiency of $\beta$-cells (Leahy et al. 1992). Diabetic patients, lean or obese, show smaller increases in $\beta$-cell volume than euglycemic subjects (Kloppel et al. 1985); this has been cited as evidence that impaired $\beta$-cell compensatory growth may promote pathogenesis of type 2 diabetes. 


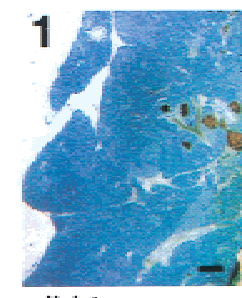

wild-type

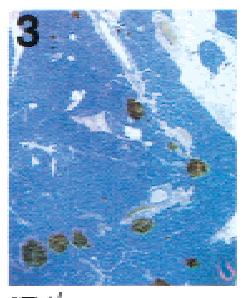

$\mathrm{IR}^{+/-}$

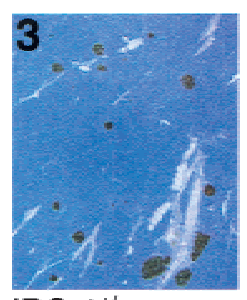

IRS- $1^{+1-}$

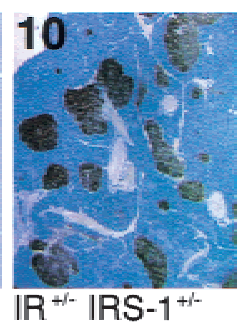

Figure 4. $\beta$-cell hyperplasia in response to deficiency for insulin receptor (IR) and IRS-1. Sectioned pancreatic tissue from male mice of the indicated genotypes was immunostained for insulin (brown) and counterstained with hematoxylin (blue). The mean pancreatic $\beta$-cell mass determined by point-counting morphometry (relative to wild-type mass, 1 ) is indicated in the upper-left corner. Animals simultaneously heterozygous for IR and IRS-1 null alleles have greater insulin resistance and $\beta$-cell mass compared to those heterozygous for IR or IRS-1. Adapted from Brüning et al (1997), with permission.

The identification of genes whose dysfunction leads to $\beta$-cell failure in type 2 diabetes has therefore been the focus of considerable effort (Swenne 1992; Bonner-Weir 1994; Kahn 1998). A small subset of type 2 diabetes known as maturity onset diabetes in the young (MODY; Winter and Silverstein 2000) results from mutations in genes encoding proteins critical to $\beta$-cell maturation and function, including glucokinase or transcription factors like hepatic nuclear factors (HNF)- $1 \alpha, \mathrm{HNF}-1 \beta$, $\mathrm{HNF}-4 \alpha$, or Ipf1/Pdx1. In these patients, insulin responsiveness may be normal or only modestly impaired, but primary defects in the $\beta$-cell lead to inadequate insulin secretion.

\section{Roles of insulin signaling in preventing $\beta$-cell failure}

Insulin binding to the insulin receptor (IR), a cell-surface transmembrane tyrosine kinase, stimulates IR autophosphorylation and subsequent tyrosine phosphorylation of cytosolic proteins collectively called insulin receptor substrates (IRS). Recent evidence suggests that both IR and IRS- 2 may be required for $\beta$-cell growth in postnatal animals. Withers et al. (1998) reported that germ-line IRS-2 inactivation in mice resulted in overt diabetes. As predicted, Irs-2 $2^{-/-}$mice had frank insulin resistance in peripheral organs including liver and skeletal muscle. Unexpectedly, Irs-2 ${ }^{-/-}$mice also had $\beta$-cell failure, manifesting as inappropriately reduced $\beta$-cell mass and relative hypoinsulinemia, leading to overt diabetes by $10 \mathrm{wk}$ of age. In contrast, IRS-1 inactivation caused moderate insulin resistance but not overt diabetes because compensatory $\beta$-cell growth and insulin secretion matched the increased insulin demand in these animals (Araki et al. 1994; Tamemoto et al. 1994; Brüning et al. 1997; Fig. 4). The receptors for insulin and Igf-1 are known regulators of IRS-2, and recent studies suggest that these receptors promote $\beta$-cell functions required to prevent $\beta$-cell failure (Withers et al. 1999; Kulkarni et al. 1999).

These data are consistent with the possibility that insulin receptor, Igf-1R, IRS proteins, and other insulin signal transduction components (including insulin itself) regulate postnatal islet mass and $\beta$-cell responsiveness to glucose. These studies did not address whether deficiency for insulin receptor, Irs-2, or Igf1- $R$ leads to $\beta$-cell failure by cell-autonomous or cell-nonautonomous mechanisms, nor do they rule out the possibility that accumulated developmental pancreatic defects resulting from mutation of these genes impair postnatal $\beta$-cell functions. Thus, in the future, it may be important to adapt both tissue-specific and temporally specific gene inactivation strategies to dissect postnatal roles of these and other genes in compensatory islet responses (Ahlgren et al. 1998; Kulkarni et al. 1999; Postic et al 1999; Vasioukhin et al. 1999).

In humans and rodents with type 2 diabetes, decreased levels of IRS-1 and insulin receptor expression are observed in insulin target tissues. However, several studies have demonstrated the absence of mutations in the genes encoding insulin signaling components in the vast majority of human diabetes cases (e.g., Bernal et al. 1998). While it remains possible that genetic or acquired defects in insulin signal transduction components underlie some forms of human type 2 diabetes (Withers and White 2000), it is likely that additional signaling pathways are involved in the majority of defects leading to insulin resistance and $\beta$-cell failure.

\section{Role of TGF- $\beta$ signaling in preventing $\beta$-cell failure}

Characteristic features of $\beta$-cell failure include relative islet hypoplasia, hypoinsulinemia, impaired $\beta$-cell glucose sensing, and dysregulated glucose homeostasis. As described above, phenotypes in mice with mutations in ActRIIA and ActRIIB suggest that activin receptor-mediated signaling is required to prevent $\beta$-cell failure (Kim et al. 2000). Smad2 is a signaling target of both ActRIIA and ActRIIB, and recent studies reveal a role for Smad2 in preventing $\beta$-cell failure in adult mice. Compared to wild-type siblings, Smad2 ${ }^{\mathrm{mh} 1 /+}$ heterozygotes have inappropriate $\beta$-cell hypoplasia, hypoinsulinemia, impaired glucose tolerance, and significant insulin resistance (Osborne et al. 2000). Simultaneous insulin resistance and $\beta$-cell hypoplasia are phenotypes also observed in mice with homozygous Irs-2 inactivation (Withers et al. 1998). Samad et al. (1999) provide evidence of possible roles for dysregulated TGF- $\beta$ and tumor necrosis factor- $\alpha$ signaling in promoting insulin resistance in humans. Thus, the data motivate investigation of possible connections between TGF- $\beta$ signaling and insulin resistance.

\section{Summary, future directions, and implications for human pancreatic diseases}

Investigation of intercellular signaling pathways that govern embryonic pancreas development has proven use- 
ful for identifying candidate genes for several human diseases, including annular pancreas, pancreas divisum, heterotopic pancreas, pancreatic hypoplasia, splenic hypoplasia (hyposplenism), congenital absence of islets, and susceptibility to type 2 diabetes mellitus (Table 1). Demonstration that mutations in ActRIIB or Smad2 promote diabetes susceptibility in mice motivates linkage analysis of orthologous human genes in patients with diabetes. Similar logic recently led to identification of $I p f 1 / P d x 1$ and NeuroD as susceptibility genes in type 2 diabetes (Stoffers et al. 1997a,b; Hani et al. 1999; Macfarlane et al. 1999; Malecki et al. 1999). Growth in knowledge about embryonic pancreas development should motivate molecular investigations of the pancreas in gestation, childhood, and advanced age, developmental stages with unique pancreatic disorders that remain relatively underexplored by the modern biomedical effort.

Pathogenesis of type 2 diabetes remains unexplained. In one prevailing hypotheses, inherited susceptibility to this disease is polygenic, involving accumulation of many genetic defects that influence host insulin requirements and supply. A growing number of recent studies in mice have shown that interactions between only a few predisposing alleles are sufficient to reproduce the genetic predisposition to type 2 diabetes, a pattern of oligogenic inheritance (Kido et al. 2000). Thus, mice transheterozygous for mutations in IR and Irs-1 (Brüning et al. 1997), IGF-1 receptor, and Irs-2 (Withers et al. 1999) or for the type II activin receptors ActRIIA and ActRIIB (Kim et al. 2000) manifest an increased prevalence of diabetic phenotypes. Accumulation of human diabetes susceptibility genes should facilitate testing of this oligogenic pathogenesis model for type 2 diabetes mellitus.

The genetic basis for neoplastic transformation in the pancreas remains poorly understood (for review, see Moskaluk and Kern 1998) but is likely to benefit from elucidation of intercellular signaling functions in pancreatic growth control. In addition to their roles in embryonic pancreas growth and differentiation, Patched, Smad2, and Smad4 have previously established tumor suppressor functions in humans. Likewise, genes like Pbx1, Meis, and Sonic hedgehog that may pattern embryonic pancreas development, are known human protooncogenes. It is also well established that mutations in FGF, TGF- $\beta$, Hedgehog, Wnt, and EGF signaling components promote malignant growth. It will be interesting to determine what role, if any, these pathways play in pathogenesis of pancreatic carcinomas, the fourth leading cause of cancer deaths in western countries.

The isolation and use of hematopoietic stem cells is transforming the practice of medicine, and the reported purification of stem cells for other tissues holds particular promise for novel treatments and functional restoration of the pancreas. Cell-extrinsic signals provide an accessible means of manipulating stem cell growth and differentiation (Schuldiner et al. 2000): whether to induce endodermal development of embryonic stem cells or to stimulate islet cell differentiation from the as yet elusive pancreatic stem cell. Understanding the function of cell signals in pancreatic development and cellular differentiation may provide essential tools to direct in vitro differentiation of transplantable, functioning islets from stem cells or to stimulate pancreatic growth in vivo.

Genetic and biochemical relationships between components of the signaling pathways reviewed here have been elucidated largely from in vitro studies, and examination of axial patterning, organogenesis, and cell fate determination in Drosophila melanogaster, Caenorhabditis elegans, and Xenopus laevis. Given apparent conservation of insulin activities, insulin regulation, or insulin signal transduction machinery (Bohni et al. 1999; Ogg et al. 1997; Henry et al. 1996; Beck and Slack 1999; Kelly and Melton 2000), studies in these organisms are likely to remain important for understanding the developmental genetics and function of insulin-producing cells. The evolutionary conservation of insulin signaling and the profound impact of pancreatic diseases on human health insure continuing interest and relentless growth in our understanding of the signals governing pancreas development and function.

\section{Acknowledgments}

We thank Erin Harmon and Drs. Yuichi Hori, Lori Sussel, Eric Rulifson, Pedro Herrera, Vincenzo Cirulli, Dicki Hertel, Jeffrey Bluestone, and Christian Vaisse for helpful comments on the manuscript; C.R. Kahn for permission to reprint data in Figure 4; and P. Herrera for permission to describe unpublished data. M.H. was supported by the Sandler Family Supporting Foundation and a career development award from the Juvenile Diabetes Foundation. S.K.K. was supported by a Pew Biomedical Scholars award, the Donald E. and Delia B. Baxter Foundation, a career development award from the American Diabetes Association, and by the National Institutes of Health.

\section{Note added in proof}

Expression of a dominant-negative (dn) form of FGF receptor, FGFR1c, in mouse $\beta$-cells led to reduced postnatal $\beta$-cell mass, disorganized islets, and decreased $\beta$-cell expression of the glucose transporter Glut-2 and the proinsulin processing enzyme $\mathrm{PCl} / 3$ (Hart et al. 2000). Embryonic pancreas growth, differentiation, and morphogenesis in animals expressing dnFGFR1c was not detectably perturbed. Impaired glucose sensing, and decreased proinsulin processing in these animals culminated in age-dependent overt type 2 diabetes. Thus, FGF signaling may be required to maintain essential postnatal functions of mouse pancreatic $\beta$-cells.

\section{References}

Ahlgren, U., Jonsson, J., and Edlund, H. 1996. The morphogenesis of the pancreatic mesenchyme is uncoupled from that of the pancreatic epithelium in IPF1/PDX1-deficient mice. Development 122: 1409-1416.

Ahlgren, U., Pfaff, S.L., Jessell, T.M., Edlund, T., and Edlund, H. 1997. Independent requirement for ISL1 in formation of pancreatic mesenchyme and islet cells. Nature 385: 257-260.

Ahlgren, U., Jonsson, J., Jonsson, L., Simu, K., and Edlund, H. 1998. $\beta$-cell-specific inactivation of the mouse $\operatorname{Ipf} 1 / \mathrm{Pdx} 1$ 
gene results in loss of the $\beta$-cell phenotype and maturity onset diabetes. Genes \& Dev. 12: 1763-1768.

Alexandre C., Lecourtois, M., and Vincent, J. 1999. Wingless and Hedgehog pattern Drosophila denticle belts by regulating the production of short-range signals. Development 126: $5689-5698$.

Anderson, D.J., Groves, A., Lo, L., Ma, Q., Shah, N.M., and Sommer, L. 1997. Cell lineage determination and the control of neuronal identity in the neural crest. Cold Spring Harbor Symp. Quant. Biol. 62: 493-504.

Apelqvist, A., Ahlgren, U., and Edlund, H. 1997. Sonic Hedgehog directs specialized mesoderm differentiation in the intestine and pancreas. Curr. Biol. 7: 801-804.

Apelqvist, A., Li, H., Sommer, L., Beatus, P., Anderson, D.J., Honjo, T., Hrabe de Angelis, M., Lendahl, U., and Edlund, H. 1999. Notch signalling controls pancreatic cell differentiation. Nature 400: 877-881.

Araki, E., Lipes, M.A., Patti, M.E., Bruning, J.C., Haag III, B., Johnson, R.S., and Kahn, C.R. 1994. Alternative pathway of insulin signalling in mice with targeted disruption of the IRS-1 gene. Nature 372: 186-190.

Artavanis-Tsakonas, S., Rand, M.D., and Lake, R.J. 1999. Notch signaling: Cell fate control and signal integration in develoment. Science 284: 770-776.

Bailey, E.C., Scott, M.P., and Johnson, R.L. 2000. Hedgehog signaling in animal development and human disease. Ernst Schering Res. Found. Workshop 29: 211-235.

Baker, N.E. 2000. Notch signaling in the nervous system: Pieces still missing from the puzzle. Bioessays 22: 264-273.

Baldwin, W.M. 1910. Specimen of annular pancreas. Anat. Rec. 4: 299-304.

Beck, C.W. and Slack, J.M. 1999. Gut specific expression using mammalian promoters in transgenic Xenopus laevis. Mech. Dev. 88: 221-227.

Belloni, E., Muenke, M., Roessler, E., Traverso, G., Siegel-Bartelt, J., Frumkin, A., Mitchell, H.F., Donis-Keller, H., Helms, C., Hing, A.V., et al. 1996. Identification of Sonic hedgehog as a candidate gene responsible for holoprosencephaly. Nat. Genet. 14: 353-356.

Bernal, D., Almind, K., Yenush, L., Ayoub, M., Zhang, Y., Rosshani, L., Larsson, C., Pedersen, O., and White, M.F. 1998. Insulin receptor substrate- 2 amino acid polymorphisms are not associated with random type 2 diabetes among Caucasians. Diabetes 47: 976-979.

Bitgood, M.J. and McMahon, A.P. 1995. Hedgehog and BMP genes are coexpressed at many diverse sites of cell-cell interaction in the mouse embryo. Dev. Biol. 172: 126-138.

Blader, P., Fischer, N., Gradwohl, G., Guillemont, F., and Strahle, U. 1997. The activity of neurogenin1 is controlled by local cues in the zebrafish embryo. Development 124: 4557-4569.

Bohni, R., Riesgo-Escovar, J., Oldham, S., Brogiolo, W., Stocker, H., Andruss, B.F., Beckingham, K., and Hafen, E. 1999. Autonomous control of cell and organ size by CHICO, a Drosophila homolog of vertebrate IRS1-4. Cell 97: 865-875.

Bonner-Weir, S. 1994. Regulation of pancreatic $\beta$-cell mass in vivo. Recent Prog. Horm. Res. 49: 91-104.

Bosco, D. and Meda, P. 1997. Reconstructing islet function in vitro. Adv. Exp. Med. Biol. 426: 285-298.

Bosco, D., Meda, P., Halban, P.A., and Rouiller, D.G. 2000. Importance of cell-matrix interactions in rat islet $\beta$-cell secretion in vitro: Role of $\alpha 6 \beta 1$ integrin. Diabetes 49: 233-243.

Briscoe, J., Pierani, A., Jessell, T.M., and Ericson, J. 2000. A homeodomain protein code specifies progenitor cell identity and neuronal fate in the ventral neural tube. Cell 101: 435445 .
Brooke, N.M., Garcia-Fernandez, J., and Holland, P.W. 1998. The ParaHox gene cluster is an evolutionary sister of the Hox gene cluster. Nature 392: 920-922.

Brüning, J.C., Winnay, J.N., Hayashi, T., Horsch, D., Accili, D. Goodyear, L.J., and Kahn, C.R. 1997. Development of a novel polygenic model of NIDDM in mice heterozygous for $I R$ and IRS-1 null alleles. Cell 88: 531-572.

Brush, J.M. 1944. Initial stabilization of the diabetic child. Am. J. Dis. Child 67: 429-444.

Cabrera, C.V. 1990. Lateral inhibition and cell fate during neurogenesis in Drosophila. Development 109: 733-742.

Celli, G., LaRochelle, W.J., Mackem, S., Sharp, R., and Merlino, G. 1998. Soluble dominant-negative receptor uncovers essential roles for fibroblast growth factors in multi-organ induction and patterning. EMBO J. 17: 1642-1655.

Cepko, C.L., Ryder, E.F., Austin, C.P., Walsh, C., and Fekete, D.M. 1993. Lineage analysis using retrovirus vectors. In Guide to Techniques in Mouse Development (ed. P.M. Wassarman and M.L. DePamphilis), pp. 933-961. Academic Press, Boston.

Chiang, C., Litingtung, Y., Lee, E., Young, K.E., Corden, J.L., Westphal, H., and Beachy, P.A. 1996. Cyclopia and defective axial patterning in mice lacking Sonic hedgehog gene function. Nature 383: 407-413.

Cirulli, V., Crisa, L., Beattie, G.M., Mally, M.I., Lopez, A.D., Fannon, A., Ptasznik, A., Inverardi, L., Ricordi, C., Deerinck, T., et al. 1998. KSA antigen Ep-CAM mediates cell-cell adhesion of pancreatic epithelial cells: Morphoregulatory roles in pancreatic islet development. J. Cell Biol. 140: 1519-1534.

Cirulli, V., Beattie, G.M., Klier, G., Ellisman, M., Ricordi, C., Quaranta, V., Frasier, F., Ishii, J.K., Hayek, A., and Salomon, D.R. 2000. Expression and function of $\alpha(\mathrm{v}) \beta(3)$ and $\alpha(\mathrm{v}) \beta(5)$ integrins in the developing pancreas: Roles in the adhesion and migration of putative endocrine progenitor cells. J. Cell Biol. 150: 1445-1460.

Cooper, M.K., Porter, J.A., Young, K.E., and Beachy, P.A. 1998. Teratogen-mediated inhibition of target tissue response to Shh signaling. Science 280: 1603-1607.

Cotton, P.B. 1980. Congenital anomaly of pancreas divisum as cause of obstructive pain and pancreatitis. Gut 21: 105-114.

Coulier, F., Burtey, S., Chaffanet, M., Birg, F., and Birnbaum, D. 2000. Ancestrally-duplicated paraHOX gene clusters in humans. Int. J. Oncol. 17: 439-444.

Crisera, C.A., Maldonado, T.S., Kadison, A.S., Li, M., Alkasab, S.L., Longaker, M.T., and Gittes, G.K. 2000. Transforming growth factor- $\beta 1$ in the developing mouse pancreas: A potential regulator of exocrine differentiation. Differentiation 65: 255-259.

Dahl, U., Sjodin, A., and Semb, H. 1996. Cadherins regulate aggregation of pancreatic $\beta$-cells in vivo. Development 122: 2895-2902.

Deltour, L., Leduque, P., Paldi, A., Ripoche, M.A., Dubois, P., and Jami, J. 1991. Polyclonal origin of pancreatic islets in aggregation mouse chimaeras. Development 112: 11151121.

Dieterlen-Lièvre, F. 1970. Tissus exocrine et endocrine du pancréas chez l'embryon de Poulet: Origine et interactions tissulaires dans la différenciation. Dev. Biol. 22: 138-156.

Dieterlen-Lièvre, F. and Beaupain, D. 1974. Étude immunocytologique de la différentiation du pancréas endocrine chez l'embryon de Poulet. I. Ilots a insuline. Gen. Comp. Endocinol. 22: 62-69.

Dohrmann, C., Gruss, P., and Lemaire, L. 2000. Pax genes and the differentiation of hormone-producing endocrine cells in the pancreas. Mech. Dev. 92: 47-54.

Drucker, D.J. 1998. Glucagon-like peptides. Diabetes 47: 159-169. 
Dutta, S., Bonner-Weir, S., Montminy, M., and Wright, C. 1998. Regulatory factor linked to late-onset diabetes? Nature 392: 560 .

Echelard, Y., Epstein, D.J., St-Jacques, B., Shen, L., Mohler, J., McMahon, J.A., and McMahon, A.P. 1993. Sonic hedgehog, a member of a family of putative signaling molecules, is implicated in the regulation of CNS polarity. Cell 75: 14171430.

Edlund, H. 1998. Transcribing pancreas. Diabetes 47: 18171823.

Esni, F., Taljedal, I.B., Perl, A.K., Cremer, H., Christofori, G., and Semb, H. 1999. Neural cell adhesion molecule (N-CAM) is required for cell type segregation and normal ultrastructure in pancreatic islets. J. Cell Biol. 144: 325-337.

Feijen, A., Goumans, M.J., and van den Eijnden-van Raaji, A.J.M. 1994. Expression of activin subunits, activin receptors and follistatin in postimplantation mouse embryos suggests specific developmental functions for different activins. Development 120: 3621-3637.

Furukawa, M., Eto, Y., and Kojima, I. 1995. Expression of immunoreactive activin $\mathrm{A}$ in fetal rat pancreas. Endocr. $I$. 42: 63-68.

Gannon, M. and Wright, C.V.E. 1999. Endodermal patterning and organogenesis. In Cell lineage and fate determination (ed. S.A. Moody), pp. 583-615. Academic Press, San Diego.

Gittes, G.K. and Rutter, W.J. 1992. Onset of cell-specific gene expression in the developing mouse pancreas. Proc. Nat1. Acad. Sci. 89: 1128-1132.

Gittes, G.K., Galante, P.E., Hanahan, D., Rutter, W.J., and Debas, H.T. 1996. Lineage-specific morphogenesis in the developing pancreas: Role of mesenchyman factors. Development 122: 439-447.

Golosow, N. and Grobstein, C. 1962. Epitheliomesenchymal interaction in pancreatic morphogenesis. Dev. Biol. 4: 242 255.

Goodrich, L.V. and Scott, M.P. 1998. Hedgehog and Patched in neural development and disease. Neuron 21: 1243-57.

Goss, R.J. 1978. In The physiology of growth (Chapters 13,19). Academic Press, New York.

Gradwohl, G., Dierich, A., LeMeur, M., and Guillemot, F. 2000. neurogenin 3 is required for the development of the four endocrine cell lineages of the pancreas. Proc. Natl. Acad. Sci. 97: 1607-1611.

Grapin-Botton, A. and Melton, D.A. 2000. Endoderm development: From patterning to organogenesis. Trends Genet. 16: $124-130$.

Hackel, P.O., Zwick, E., Prenzel, N., and Ullrich, A. 1999. Epidermal growth factor receptors: Critical modulators of multiple receptor pathways. Curr. Opin. Cell Biol. 11: 184-189.

Hani, E.H., Stoffers, D.A., Chevre, J.C., Durand, E., Stanojevic, V., Dina, C., Habener, J.F., and Froguel, P. 1999. Defective mutations in the insulin promoter factor-1 (IPF-1) gene in late-onset type 2 diabetes mellitus. J. Clin. Investig. 104: $\mathrm{R} 41-\mathrm{R} 48$.

Harrison, K.A., Thaler, J., Pfaff, S.L., Gu, H., and Kehrl, J.H. 1999. Pancreas dorsal lobe agenesis and abnormal islets of Langerhans in Hlxb9-deficient mice. Nat. Genet. 23: 71-75.

Hart, A.W., Baeza, N., Apelqvist, A., and Edlund, H. 2000. Attenuation of FGF signalling in mouse $\beta$-cells leads to diabetes. Nature 408: 864-868.

Hayek, A., Beattie, G.M., Cirulli, V., Lopez, A.D., Ricordi, C., and Rubin, J.S. 1995. Growth factor/matrix-induced proliferation of human adult $\beta$-cells. Diabetes 44: 1458-1460.

Hebrok, M., Kim, S.K., and Melton, D.A. 1998. Notochord repression of endodermal Sonic hedgehog permits pancreas development. Genes \& Dev. 12: 1705-1713.
Hebrok, M., Kim, S.K., St. Jacques, B., McMahon, A.P., and Melton, D.A. 2000. Regulation of pancreas development by Hedgehog signaling. Development 127: 4905-4913.

Henry, G.L., Brivanlou, I.H., Kessler, D.S., Hemmati-Brivanlou, A., and Melton, D.A. 1996. TGF- $\beta$ signals and a prepattern in Xenopus laevis endodermal development. Development 122: $1007-1015$.

Herrera, P.L. 2000. Adult insulin- and glucagon-producing cells differentiate from two independent cell lineages Development 127: 2317-2322.

Herrera, P.L., Huarte, J., Sanvito, F., Meda, P., Orci, L., and Vassalli, J.D. 1991. Embryogenesis of the murine endocrine pancreas: Early expression of pancreatic polypeptide gene. Development 113: 1257-1265.

Herrera, P.L., Huarte, J., Zufferey, R., Nichols, A., Mermillod, B., Philippe, J., Muniesa, P., Sanvito, F., Orci, L., and Vassalli, J.D. 1994. Ablation of islet endocrine cells by targeted expression of hormone-promoter-driven toxigenes. Proc. Nat1. Acad. Sci. 91: 12999-13003.

Herzer, U., Crocoll, A., Barton, D., Howells, N., and Englert, C. 1999. The Wilms tumor suppressor gene wt1 is required for development of the spleen. Curr. Biol. 9: 837-840.

Hill, D. and Lebenthal, E. 1993. Congenital abnormalities of the exocrine pancreas. In Pancreas: Biology, pathobiology, and disease (ed. V.L.W. Go, E.P. Dimagno, J.D. Gardner, E. Lebenthal, H.A. Reber and G.A. Scheele), pp. 1029-1040. Raven, New York.

Holst, J.J. 1999. Glucagon-like peptide-1, a gastrointestinal hormone with a pharmaceutical potential. Curr. Med. Chem. 6: $1005-1017$.

Hughes, H. 1956. An experimental study of regeneration in the islets of Langerhans with reference to the theory of balance. Acta Anat. 27: 1-61.

Jacquemin, P., Durviaux, S.M., Jensen, J., Godfraind, C., Gradwohl, G., Guillemot, F., Madsen, O.D., Carmeliet, P., Dewerchin, M., Collen, D., et al. 2000. Transcription factor hepatocyte nuclear factor 6 regulates pancreatic endocrine cell differentiation and controls expression of the proendocrine gene ngn3. Mol. Cell. Biol. 20: 4445-4454.

Jensen, J., Heller, R.S., Funder-Nielsen, T., Pedersen, E.E., Lindsell, C., Weinmaster, G., Madsen, O.D., and Serup, P. 2000a. Independent development of pancreatic $\alpha$ - and $\beta$-cells from neurogenin3-expressing precursors: A role for the notch pathway in repression of premature differentiation. Diabetes 49: $163-176$.

Jensen, J., Pedersen, E.E., Galante, P., Hald, J., Heller, R.S., Ishibashi, M., Kageyama, R., Guillemot, F., Serup, P., and Madsen, O.D. 2000b. Control of endodermal endocrine development by Hes-1. Nat. Genet. 24: 36-44.

Jonsson, J., Carlsson, L., Edlund, T., and Edlund, H. 1994. Insulin-promoter-factor 1 is required for pancreas development in mice. Nature 371: 606-609.

Kahn, B.B. 1998. Type 2 diabetes: When insulin secretion fails to compensate for insulin resistance. Cell 92: 593-596.

Kahn, C.R. 1994. Insulin action, diabetogenes and the cause of Type II diabetes. Diabetes 43: 1066-1084.

Kahn, S.E. 2000. The importance of the $\beta$-cell in the pathogenesis of type 2 diabetes mellitus. Am. J. Med. 108: 2S-8S.

Kantengwa, S., Baetens, D., Sadoul, K., Buck, C.A., Halban, P.A., and Rouiller, D.G. 1997. Identification and characterization of $\alpha 3 \beta 1$ integrin on primary and transformed rat islet cells. Exp. Cell Res. 237: 394-402.

Kelly, O.G. and Melton, D.A. 2000. Development of the pancreas in Xenopus laevis. Dev. Dyn. 218: 615-627.

Kido, Y., Burks, D.J., Withers, D., Bruning, J.C., Kahn, C.R., White, M.F., and Accili, D. 2000. Tissue-specific insulin re- 
sistance in mice with mutations in the insulin receptor, IRS1, and IRS-2. J. Clin. Investig. 105: 199-205.

Kieffer, T.J. and Habener, J.F. 1999. The glucagon-like peptides. Endocr. Rev. 20: 876-913.

Kim, S.K. and Melton, D.A. 1998. Pancreas development is promoted by cyclopamine, a hedgehog signaling inhibitor. Proc. Nat1. Acad. Sci. 95: 13036-13041.

Kim, S.K., Hebrok, M., and Melton, D.A. 1997a. Notochord to endoderm signaling is required for pancreas development. Development 124: 4243-4253.

- 1997b. Pancreas development in the chick embryo. Cold Spring Harbor Symp. Quant. Biol. 62: 377-383.

Kim, S.K., Hebrok, M., Li, E., Oh, S.P., Schrewe, H., Harmon, E.B., Lee, J.S., and Melton, D.A. 2000. Activin receptor patterning of foregut organogenesis. Genes \& Dev. 14: 1866 1871.

Kloppel, G., Lohr, M., Habich, K., Oberholzer, M., and Heitz, P.U. 1985. Islet pathology and the pathogenesis of type 1 and type 2 diabetes mellitus revisited. Surv. Synth. Pathol. Res. 4: 110-125.

Krakowski, M.L., Kritzik, M.R., Jones, E.M., Krahl, T., Lee, J., Arnush, M., Gu, D., Mroczkowski, B., and Sarvetnick, N. 1999a. Transgenic expression of epidermal growth factor and keratinocyte growth factor in $\beta$-cells results in substantial morphological changes. J. Endocrinol. 162: 167-175.

Krakowski, M.L., Kritzik, M.R., Jones, E.M., Krahl, T., Lee, J., Arnush, M., Gu, D., and Sarvetnick, N. 1999b. Pancreatic expression of keratinocyte growth factor leads to differentiation of islet hepatocytes and proliferation of duct cells. Am. J. Pathol. 154: 683-691.

Krapp, A., Knofler, M., Ledermann, B., Burki, K., Berney, C., Zoerkler, N., Hagenbuchle, O., and Wellauer, P.K. 1998. The bHLH protein PTF1-p48 is essential for the formation of the exocrine and the correct spatial organization of the endocrine pancreas. Genes \& Dev. 12: 3752-3763.

Krumlauf, R. 1994. Hox genes in vertebrate development. Cell 78: 191-201.

Kulkarni, R.N., Brüning, J.C., Winnay, J.N., Postic, C., Magnuson, M.A., and Kahn, C.R. 1999. Tissue-specific knockout of the insulin receptor in pancreatic $\beta$ cells creates an insulin secretory defect similar to that in type 2 diabetes. Cell 96: $329-339$.

Lammert, E., Brown, J., and Melton, D.A. 2000. Notch gene expression during pancreatic organogenesis. Mech. Dev. 94: 199-203.

Leahy, J.L., Bonner-Weir, S., and Weir, G.C. 1992. $\beta$-cell dysfunction induced by chronic hyperglycemia: Current ideas on mechanism of impaired glucose-induced insulin secretion. Diabetes Care 15: 442-455.

Le Bras, S., Miralles, F., Basmaciogullari, A., Czernichow, P., and Scharfmann, R. 1998. Fibroblast growth factor 2 promotes pancreatic epithelial cell proliferation via functional fibroblast growth factor receptors during embryonic life. Diabetes 47: 1236-1242.

Lecco, T.M. 1910. Zur Morphologie des Pankreas annulare. Sitzungsber. Oesterr. Akad. Wiss. Math.-Natwiss. CL 119: 391-406.

Lettice, L.A., Purdie, L.A., Carlson, G.J., Kilanowski, F., Dorin, J., and Hill, R.E. 1999. The mouse bagpipe gene controls development of axial skeleton, skull, and spleen. Proc. Natl. Acad. Sci. 96: 9695-9700.

Li, H., Arber, S., Jessell, T.M., and Edlund, H. 1999. Selective agenesis of the dorsal pancreas in mice lacking homeobox gene Hlxb9. Nat. Genet. 23: 67-70.

Litingtung, Y., Lei, L., Westphal, H., and Chiang, C. 1998. Sonic hedgehog is essential to foregut development. Nat. Genet.
20: $58-61$.

Lu, J., Chang, P., Richardson, J.A., Gan, L., Weiler, H., and Olson, E.N. 2000. The basic helix-loop-helix transcription factor capsulin controls spleen organogenesis. Proc. Natl. Acad. Sci. 97: 9525-9530.

Macfarlane, W.M., Frayling, T.M., Ellard, S., Evans, J.C., Allen, L.I., Bulman, M.P., Ayres, S., Shepherd, M., Clark, P., Millward, A., et al. 1999. Missense mutations in the insulin promoter factor-1 gene predispose to type 2 diabetes. I. Clin. Investig. 104: R33-R39.

Malecki, M.T., Jhala, U.S., Antonellis, A., Fields, L., Doria, A., Orban, T., Saad, M., Warram, J.H., Montminy, M., and Krolewski, A.S. 1999. Mutations in NEUROD1 are associated with the development of type 2 diabetes mellitus. Nat. Genet. 23: 323-328.

Manova, K., De Leon, V., Angeles, M., Kalantry, S., Giarre, M., Attisano, L., Wrana, J., and Bachvarova, R.F. 1995. mRNAs for activin receptors II and IIB are expressed in mouse oocytes and in the epiblast of pregastrula and gastrula stage mouse embryos. Mech. Dev. 49: 3-11.

Martin B.C., Warram, J.H., Krolewski, A.S., Bergman, R.N., Soeldner, J.S., and Kahn, C.R. 1992. Role of glucose and insulin resistance in development of type 2 diabetes mellitus: Results of a 25-year follow-up study. Lancet 340: 925-929.

Massagué, J. and Chen, Y.G. 2000. Controlling TGF- $\beta$ signaling. Genes \& Dev. 14: 627-644.

McMahon, A.P. 2000. More surprises in the Hedgehog signaling pathway. Cell 100: 185-188.

Miettinen, P.J., Huotari, M., Koivisto, T., Ustinov, J., Palgi, J., Rasilainen, S., Lehtonen, E., Keski-Oja, J., and Otonkoski, T. 2000. Impaired migration and delayed differentiation of pancreatic islet cells in mice lacking EGF-receptors. Development 127: 2617-2627.

Milenkovic L., Goodrich, L.V., Higgins, K.M., and Scott, M.P. 1999. Mouse patched1 controls body size determination and limb patterning. Development 126: 4431-4440.

Miralles, F., Battelino, T., Czernichow, P., and Scharfmann, R. 1998a. TGF- $\beta$ plays a key role in morphogenesis of the pancreatic islets of Langerhans by controlling the activity of the matrix metalloproteinase MMP-2. J. Cell Biol. 143: 827-836.

Miralles, F., Czernichow, P., and Scharfmann, R. 1998b. Follistatin regulates the relative proportions of endocrine versus exocrine tissue during pancreatic development. Development 125: 1017-1024.

Miralles, F., Czernichow, P., Ozaki, K., Itoh, N., and Scharfmann, R. 1999. Signaling through fibroblast growth factor receptor $2 \mathrm{~b}$ plays a key role in the development of the exocrine pancreas. Proc. Nat1. Acad. Sci. 96: 6267-6272.

Montanya, E., Nacher, V., Biarnes, M., and Soler, J. 2000. Linear correlation between $\beta$-cell mass and body weight throughout the lifespan in Lewis rats: Role of $\beta$-cell hyperplasis and hypertrophy. Diabetes 49: 1341-1346.

Moskaluk, C.A. and Kern, S.E. 1998. Molecular genetics of pancreatic carcinoma. In Pancreatic cancer pathogenesis, diagnosis, and treatment (ed. H.A. Reber), pp. 3-20. Humana, Totowa, NJ.

Nguyen, H.Q., Danilenko, D.M., Bucay, N., DeRose, M.L., Van, G.Y., Thomason, A., and Simonet, W.S. 1996. Expression of keratinocyte growth factor in embryonic liver of transgenic mice causes changes in epithelial growth and differentiation resulting in polycystic kidneys and other organ malformations. Oncogene 12: 2109-2119.

Nicholson M.L., Windmill, D.C., Horsburgh, T., and Harris , K.P. Influence of allograft size to recipient body-weight ratio on the long-term outcome of renal transplantation. Br. J. Surg. 87: 314-319. 
Nielsen J.H., Svensson, C., Galsgaard, E.D., Moldrup, A., and Billestrup, N. 1999. $\beta$ cell proliferation and growth factors. J. Mol. Med. 77: 62-66.

Nomura, M. and Li, E. 1998. Smad2 role in mesoderm formation, left-right patterning and craniofacial development. $\mathrm{Na}$ ture 393: 786-790.

Offield, M.F., Jetton, T.L., Labosky, P.A., Ray, M., Stein, R., Magnuson, M.A., Hogan, B.L.M., and Wright, C.V.E. 1996. PDX-1 is required for pancreatic outgrowth and differentiation of the rostral duodenum. Development 122: 983-995.

Ogawa, K., Abe, K., Kurosawa, N., Kurohmaru, M., Sugino, H., Takahashi, M., and Hayashi, Y. 1993. Expression of $\alpha, \beta$ A and $\beta$ B subunits of inhibin or activin and follistatin in rat pancreatic islets. FEBS Lett. 319: 217-220.

Ogg, S., Paradis, S., Gottlieb, S., Patterson, G.I., Lee, L., Tissenbaum, H.A., and Ruvkun, G. 1997. The Fork head transcription factor DAF-16 transduces insulin-like metabolic and longevity signals in C. elegans. Nature 389: 994-999.

Oh, S.P. and Li, E. 1997. The signaling pathway mediated by the type IIB activin receptor controls axial patterning and lateral asymmetry in the mouse. Genes \& Dev. 11: 1812-1826.

Orci L. 1982. Macro- and micro-domains in the endocrine pancreas. Diabetes 6: 538-565.

Orci, L. and Unger, R.H. 1975. Functional subdivision of islets of Langerhans and possible role of D cells. Lancet 2: 12431244.

Osborne, D., Lee, J.S., Harmon, E.B., Ko, A., Zhang, A.Y., and Kim, S.K. 2000. Smad2 disruption impairs pancreatic $\beta$-cell function and insulin action in mice. Submitted.

Peers, B., Sharma, S., Johnson, T., Kamps, M., and Montminy, M. 1995. The Pancreatic islet factor STF-1 binds cooperatively with $\mathrm{Pbx}$ to a regulatory element in the somatostatin promoter: Importance of the FPWMK motif and of the homeodomain. Mol. Cell. Biol. 15: 7091-7097.

Percival, A.C. and Slack, J.M. 1999. Analysis of pancreatic development using a cell lineage label. Exp. Cell Res. 247: 123132.

Pictet, R. and Rutter, W.J. 1972. Development of the embryonic endocrine pancreas. In Handbook of physiology (ed. R.O. Greep, E.B. Astwood, D.F. Steiner, N. Freinkel, and S.R. Geiger), Vol. 1, pp. 25-66. American Physiological Society, Washington, DC.

Postic, C., Shiota, M., Niswender, K.D., Jetton, T.L., Chen, Y., Moates, J.M., Shelton, K.D., Lindner, J., Cherrington, A.D., and Magnuson, M.A. 1999. Dual roles for glucokinase in glucose homeostasis as determined by liver and pancreatic $\beta$ cell-specific gene knock-outs using Cre recombinase. J. Biol. Chem. 274: 305-315.

Ramalho-Santos, M., Melton, D.A., and McMahon, A.P. 2000. Hedgehog signals regulate multiple aspects of gastrointestinal development. Development 127: 2763-2772.

Rauskolb, C. and Irvine, K.D. 1999. Notch-mediated segmentation and growth control of the Drosophila leg. Dev. Biol. 210: 339-350.

Ritvos, O., Tuuri, T., Eramaa, M., Sainio, K., Hilden, K., Saxen, L., and Gilbert, S.F. 1995. Activin disrupts epithelial branching morphogenesis in developing glandular organs of the mouse. Mech. Dev. 50: 229-245.

Roberts, C.W., Shutter, J.R., and Korsmeyer, S.J. 1994. Hox11 controls the genesis of the spleen. Nature 368: 747-749.

Roberts, D.J., Johnson, R.L., Burke, A.C., Nelson, C.E., Morgan, B.A., and Tabin, C. 1995. Sonic hedgehog is an endodermal signal inducing BMP-4 and Hox genes during induction and regionalization of the chick hindgut. Development 121: 3163-3174.

Roberts, D.J., Smith, D.M., Goff, D.J., and Tabin, C.J. 1998.
Epithelial-mesenchymal signaling during the regionalization of the chick gut. Development 125: 2791-2801.

Rouiller, D.G., Cirulli, V., and Halban, P.A. 1991. Uvomorulin mediates calcium-dependent aggregation of islet cells, whereas calcium-independent cell adhesion molecules distinguish between islet cell types. Dev. Biol. 148: 233-242.

Rutter, W.J., Pictet, R.L., Harding, J.D., Chirgwin, J.M., MacDonald, R.J., and Przybyla, A.E. 1978. An analysis of pancreatic development: Role of mesenchymal factor and other extracellular factors. Symp. Soc. Dev. Biol. 35: 205-227.

Samad, F., Uysal, K.T., Wiesbrock, S.M., Pandey, M., Hotamisligil, G.S., and Loskutoff, D.J. 1999. Tumor necrosis factor alpha is a key component in the obesity-linked elevation of plasminogen activator inhibitor 1. Proc. Natl. Acad. Sci. 96: 6902-6907.

Sander, M. and German, M.S. 1997. The $\beta$ cell transcription factors and development of the pancreas. I. Mol. Med. 75: 327-340.

Sanvito, F., Herrera, P.L., Huarte, J., Nichols, A., Montesano, R., Orci, L., and Vassalli, J.D. 1994. TBF- $\beta 1$ influences the relative development of the exocrine and endocrine pancreas in vitro. Development 120: 3451-3462.

Schuldiner, M., Yanuka, O., Itskovitz-Eldor, J., Melton, D.A., and Benvenisty, N. 2000. Effects of eight growth factors on the differentiation of cells derived from human embryonic stem cells. Proc. Natl. Acad. Sci. 97: 11307-11312.

Schwitzgebel, V.M., Scheel, D.W., Conners, J.R., Kalamaras, J., Lee, J.E., Anderson, D.J., Sussel, L., Johnson, J.D., and German, M.S. 2000. Expression of neurogenin3 reveals an islet cell precursor population in the pancreas. Development 127: 3533-3542.

Shiozaki, S., Tajima, T., Zhang, Y.Q., Furukawa, M., Nakazato, Y., and Kojima, I. 1999. Impaired differentiation of endocrine and exocrine cells of the pancreas in transgenic mouse expressing the truncated type II activin receptor. Biochim. Biophys. Acta 1450: 1-11.

Skeath, J.B. and Carroll, S.B. 1992. Regulation of proneural gene expression and cell fate during neuroblast segregation in the Drosophila embryo. Development 114: 939-946.

Slack, J.M.W. 1995. Developmental biology of the pancreas. Development 121: 1569-1580.

Spooner, B.S., Walther, B.T., and Rutter, W.J. 1970. The development of the dorsal and ventral mammalian pancreas in vivo and in vitro. J. Cell Biol. 47: 235-246.

Stefan, Y., Meda, P., Neufeld, M., and Orci, L. 1987. Stimulation of insulin secretion reveals heterogeneity of pancreatic $\beta$ cells in vivo. J. Clin. Investig. 80: 175-183.

Stern, C.D., Yu, R.T., Kakizuka, A., Kintner, C.R., Mathews, L.S., Vale, W.W., Evans, R.M., and Umesono, K. 1995. Activin and its receptors during gastrulation and the later phases of mesoderm development in the chick embryo. Dev. Biol. 172: 192-205.

Stoffers, D.A., Feffer, J., Clarke, W.L., and Habener, J.F. 1997a. Early-onset type-II diabetes mellitus (MODY-4) linked to IPF1. Nat. Genet. 71: 138-139.

Stoffers, D.A., Zinkin, N.T., Stanojevic, V., Clarke, W.L., and Habener, J.F. 1997b. Pancreatic agenesis attributable to a single nucleotide deletion in the human IPF1 gene sequence. Nat. Genet. 15: 106-110.

Streuli, C. 1999. Extracellular matrix remodelling and cellular differentiation. Curr. Opin. Cell Biol. 11: 634-640.

Sumiya, M. and Mizuno, T. 1987. Etude immunohistologique de l'expression de glucagon dans l'endoderme pancreatique dorsal chez l'embryon precoce do Poulet. C.R. Soc. Biol. 181: 718-721.

Swenne, I. 1992. Pancreatic $\beta$-cell growth and diabetes mellitus. 
Diabetologia 35: 193-201.

Swift, G.H., Liu, Y., Rose, S.D., Bischof, L.J., Steelman, S., Buchberg, A.M., Wright, C.V., and MacDonald, R.J. 1998. An endocrine-exocrine switch in the activity of the pancreatic homeodomain protein PDX1 through formation of a trimeric complex with PBX1b and MRG1 (MEIS2). Mol. Cell. Biol. 18: $5109-5120$.

Tamemoto, H., Kadowaki, T., Tobe, K., Yagi, T., Sakura, H., Hayakawa, T., Terauchi, Y., Ueki, K., Kaburagi, Y., Satoh, S., et al. 1994. Insulin resistance and growth retardation in mice lacking insulin receptor substrate-1. Nature 372: 182-186.

Treier, M., Gleiberman, A.S., O'Connell, S.M., Szeto, D.P., McMahon, J.A., McMahon, A.P., and Rosenfeld, M.G. 1998. Multistep signaling requirements for pituitary organogenesis in vivo. Genes \& Dev. 12: 1691-1704.

Tremblay, K.D., Hoodless, P.A., Bikoff, E.K., and Robertson, E.J. 2000. Formation of the definitive endoderm in mouse is a Smad2-dependent process. Development 127: 3079-3090.

Tribioli, C. and Lufkin, T. 1999. The murine Bapx1 homeobox gene plays a critical role in embryonic development of the axial skeleton and spleen. Development 126: 5699-5711.

Trimble, E.R., Halban, P.A., Wollheim, C.B., and Renold, A.E. 1982. Functional differences between rat islets of ventral and dorsal pancreatic origin. J. Clin. Investig. 69: 405-413.

van der Zee, E., Jansen, I., Hoeben, K., Beertsen, W., and Everts, V. 1998. EGF and IL-1 $\alpha$ modulate the release of collagenase, gelatinase and TIMP-1 as well as the release of calcium by rabbit calvarial bone explants. J. Periodontal Res. 33: 65-72.

Vasioukhin, V., Degenstein, L., Wise, B., and Fuchs, E. 1999. The magical touch: Genome targeting in epidermal stem cells induced by tamoxifen application to mouse skin. Proc. Nat1. Acad. Sci. 96: 8551-8556.

Verschueren, K., Dewulf, N., Goumans, M.J., Lonnoy, O., Feijen, A., Grimsby, S., Vandi Speigle, K., ten Dijke, P., Moren, A., Vanscheeuwijck, P., et al. 1995. Expression of type I and type IB receptors for activin in midgestation mouse embryos suggests distinct functions in organogenesis. Mech. Dev. 52: 109-123.

von Mering, J. and Minkowski, O. 1889. Diabetes mellitus nach pankreasexstirpation. Zentbl. Klin. Med. 10: 393-394.

Vu, T.H. and Werb, Z. 2000. Matrix metalloproteinases: Effectors of development and normal physiology. Genes \& Dev. 14: $2123-2133$.

Weissman, I.L. 2000. Translating stem and progenitor cell biology to the clinic: Barriers and opportunities. Science 287: 1442-1446.

Wells, J.M. and Melton, D.A. 2000. Early mouse endoderm is patterned by soluble factors from adjacent germ layers. Development 127: 1563-1572.

Werb, Z. 1997. ECM and cell surface proteolysis: Regulating cellular ecology. Cell 91: 439-442.

Wessells, N.K. and Cohen, J.H. 1967. Early pancreas organogenesis: Morphogenesis, tissue interactions, and mass effects. Dev. Biol. 15: 237-270.

Winter, W.E. and Silverstein, J.H. 2000. Curr. Opin. Pediatr. 12: 388-393.

Withers, D.J. and White, M.F. 2000. Perspective: The insulin signaling system-a common link in the pathogenesis of type 2 diabetes. Endocrinology 141: 1917-1921.

Withers, D.J., Gutierrez, J.S., Towery, H., Durks, D.J., Ren, J.M., Previs, S., Zhang, T., Bernal, D., Pons, S., Shulman, G.I., et al. 1998. Disruption of IRS-2 causes type 2 diabetes in mice. Nature 391: 900-904.

Withers, D.J., Burks, D.J., Towery, H.H., Altamuro, S.L., Flint, C.L., and White, M.F. 1999. Irs-2 coordinates Igf-1 receptor- mediated $\beta$-cell development and peripheral insulin signalling. Nat. Genet. 23: 32-40.

Wrana, J.L. 2000. Regulation of Smad activity. Cell 100: 189192.

Yamaoka, T. and Itakura, M. 1999. Development of pancreatic islets. Int. J. Mol. Med. 3: 247-261.

Yamaoka, T., Idehara, C., Yano, M., Matsushita, T., Yamada, T., Li, S., Moritani, M., Hata, J., Sugino, H., Noji, S., et al. 1998. Hypoplasia of pancreatic islets in transgenic mice expressing activin receptor mutants. J. Clin. Investig. 102: 294-301.

Zaret, K.S. 2000. Liver specification and early morphogenesis. Mech. Dev. 92: 83-88. 


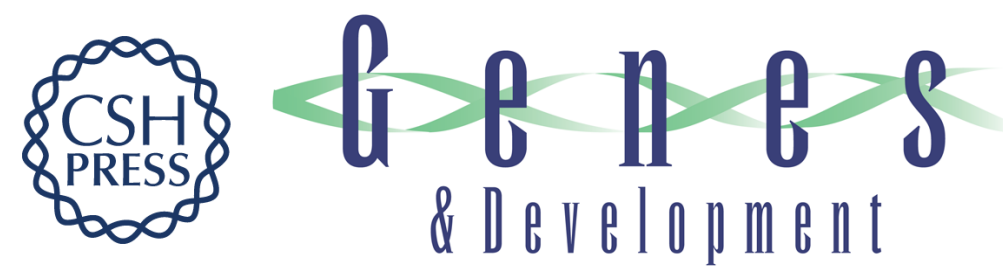

\section{Intercellular signals regulating pancreas development and function}

Seung K. Kim and Matthias Hebrok

Genes Dev. 2001, 15:

Access the most recent version at doi:10.1101/gad.859401

References This article cites 157 articles, 71 of which can be accessed free at: http://genesdev.cshlp.org/content/15/2/111.full.html\#ref-list-1

License

Email Alerting Receive free email alerts when new articles cite this article - sign up in the box at the top Service right corner of the article or click here.

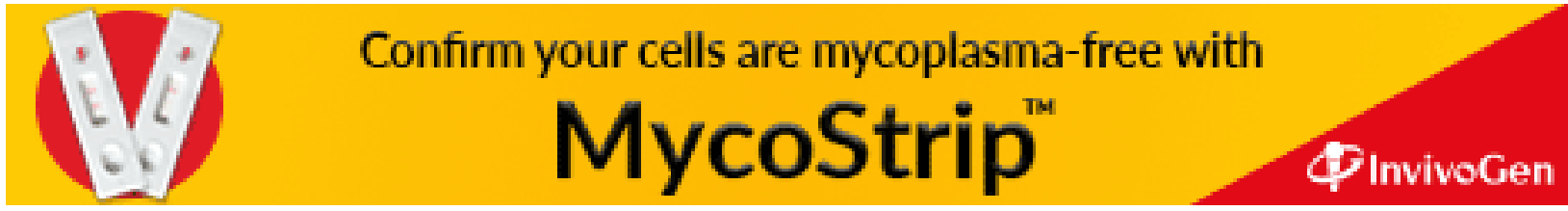

